\title{
Karel Vinařický: Mezi klasicismem a romantikou
}

\author{
Dalibor Tureček
}

\begin{abstract}
Karel Vinařický: Between Classicism and Romanticism

The study deals with Classicism in the work of Alois Josef Vinařický in the period 1820-1850, specifically. The analysis documents that in this time the markers of Classicism can be found in different constellations performing a variety of functions. In this regard the polemics between Czech Classicism and Romanticism after 1836 is especially relevant.
\end{abstract}

\section{KEYWORDS}

Czech literature of the $19^{\text {th }}$ Century, Classicism, Alois Josef Vinařický.

\section{KLÍčOVÁ SLOVA}

Literatura 19. století, klasicismus, Alois Josef Vinařický.

Soustředěná a poměrně bohatá literární tvorba Karla Vinařického (1803-1869) sahá od prvních básní dvacátých let až k posmrtnému vydání souborného díla (1871), následujícímu bezprostředně po autorově smrti a vycházejícímu ještě z jeho vlastních intencí. ${ }^{1}$ Rozprostírá se tedy v čase, sahajícím v českém literárním kontextu od etablování vlastenecké romantiky přes expanzi romantiky subjektivní a biedermeieru až k prvním výraznějším manifestacím realismu. Svým charakterem přitom Vinařického dílo jeví setrvalý, ačkoli nikoli výlučný příklon ke klasicistním principům. Otevírá tedy otázku modifikací a funkcí českého literárního klasicismu v jeho druhé či třetí vlně, a navíc ve zcela jiném

1) Viz vyjádření editora, básníkova synovce, in VINAŘICKÝ 1871; nestránkovaná příloha. 
kontextu, než jaký byl určující pro vlnu první, situovanou do konce 18. století, a pro vlnu druhou z konce desátých let a z desetiletí následujícího. Vinařického tvorba se kromě toho podstatně rozčleňuje na celky určené představou funkce a povahy poezie (vysoká klasicistní poezie s výraznou estetickou ambicí x didaktické veršování pro děti, podřizující poetiku mimoliterární funkci). Základní otázku položenou titulem budeme v následujících řádcích sledovat ve třech krocích: nejprve obhlédneme Vinařického pozici v literární historii; dále budeme sledovat informace obsažené $v$ jeho korespondenci; konečně přihlédneme $\mathrm{k}$ jeho dílům o literatuře a $\mathrm{k}$ pracím beletristickým.

\section{Pozice v literární historii}

Literárně historický obraz se započal utvářet jen několik let po Vinařického smrti. Československý Plutarch Ruperta Přecechtěla přinesl v roce 1875 poměrně podrobný autorův životopis, zato díla byla jen zmíněna letmým výčtem, ale blíže nebyla charakterizována (PǨECECHTĚL: 210-216). Ale už v 70. a 80. letech byla Vinařického tvorba odsunuta na pokraj literárního kánonu. Jan Neruda, který se svou publicistikou na vzniku onoho kánonu podstatně podílel, nerecenzoval vydání Vinařického spisů, nenapsal jeho nekrolog, ani mu překvapivě nevěnoval samostatnou pozornost $\mathrm{v}$ rámci svého jinak rozsáhlého a výběrem látky komplexního časopiseckého cyklu Podobizen, v jehož rámci jej pouze zmínil v sousedství jiných vlasteneckých kněží (NERUDA 1952: 44), respektive registroval jeho hrob jako součást nově vznikajícího vyšehradského Slavínu (NERUDA 1951: 313). Vinařického nezmínila ani Eliška Krásnohorská, když stavěla Vrchlickému a dalším parnasistům před oči ideální a podle ní závazný kánon obrozenské literatury (KRÁSNOHORSKÁ: 162).

Výraznější podobu tak dostala literárně historická reflexe Vinařického díla až na zlomu století. Roku 1898 hodnotil Jaroslav Vlček Vinařického jako jednoho „z význačných, dnes zapomenutých mravokárců svého období“ (VLČEK 1898: 107). Výrok sice vycházel z právě zmíněné marginalizace Vinařického, zároveň ale redukoval jeho dílo. Zcela zmizela estetická kvalita řady Vinařického děl, podstatná ještě pro Nerudu, podle jehož letmé zmínky Vinařický spadal do autorské kategorie „jazykoví klenotníci“ (NERUDA 1951: 313). Nesporné básnické výkony, například překlad Vergiliovy Aeneidy, tak zcela padly pod stůl 
na úkor umělecky podřadné deklamovánky Taroky, kámen mudrců (1834), „kde se [autor - DaT] posmívá oblíbené, všecky ostatní zájmy utápějící hře v karty“ a které „v letech třicátých bývaly nevyhnutelným deklamačním kusem českých besed“ (VLČEK 1898: 107-108). Klíčovým Vinařického textem se Vlčkovi a v jeho stopách i dalším - staly satirické Sněmy zvírat ze čtyřicátých let, tedy dílo zralého, dvě desetiletí působícího básníka. Vlčkův postoj byl přitom přitakavý. Sněmy zvírat měly podle něj „namířeno na zindustrialisovanou, zmechanisovanou, zmaterialisovanou, kulturu let třicátých a čtyřicátých, jak z Pařiže šiřila se na evropský východ“ (IBID.: 108). ${ }^{2}$ Oprávněná je Vlčkovi i Vinařického polemika s romantickou literaturou fantastického a subjektivně vyhroceného střihu, v níž „nevěra se zve osvětou, pokrytství věrou, lidé klesli na karikatury, na vrahy otcův, matek a dětí, na krvesmilce, na otroky vášní, na zoufalce“ (IBID.: 111). Vlček tedy s pochopením vnímal odpor proti frenetické literatuře, vůči níž se ve čtyřicátých letech nevymezovali jen klasicistně orientovaní autoři, ale také literáti píšící v duchu biedermeieru (viz TUREČEK: 133-139). Klasicistní rysy Vinařického tvorby ještě Vlčkovi nebyly důvodem $\mathrm{k}$ odsudku, jak plyne $\mathrm{z}$ hodnocení překladu poémy Jána Hollého. ${ }^{3}$ Klasicismus tedy byl Vlčkovi i pro třicátá léta integrální součástí české literatury, přičemž byly - opět ve vztahu k překladu z Hollého - shledány i jeho interference s romantikou. ${ }^{4}$

Podstatný posun v obrazu Vinařického přineslo heslo Ottova slovníku naučného (1907). Jeho autor, Jan Hanuš, tu užil dvojí strategii a rétoriku. Jádrem výkladu se stal vlastenecký příběh, soustředící se $\mathrm{k}$ autorově biografii a akcentující národní uvědomování. Klíčovými jsou motivy literatury jako prostředku takřka zázračné národní iniciace a následný popis „evangelizačního“ působení

2) Podle jiného výroku: „Vinařický právem se posmívá bezduchému mechanismu novověkého sněmování, skvělým, ale prázdným heslům parlamentním, sobeckosti poslancův, zakrývané zvučnými frazemi a líčenou kolegiálností, chytré laskavosti neobmezeně vládnoucích, nekonečnému střídání ministrův, podkupnosti a rvavosti špatné žurnalistiky“" (VLČEK 1898: 110).

3) „Vzpomeneme-li si, že Hollého Svatopluk vyšel deset let po smrti Byronově, šest let po Heinově Knize písní a jen tři léta před Máchovým Májem, máme v záplavě hexametrů Hollého na pohled přežitek velmi pozdní a zdánlivě dvojí svět vedle sebe, nesvázaný ničím společným. Ale to je pouhé zdání; Hollý se svou antikou nebyl u nás tehdy sám. Svědčí o tom nejen způsob, jakým literární veřejnost naše r. 1836 odmítla byronskou novoromantiku Máchova Máje, nýbrž i převážný směr tehdejší poesie naší, v níž ještě nepohasly klopstockovské ideály prešpurských Počátků českého básnictví. Nové a nové pokusy o zčeštění Homera, Vergilia a Horacia, Jungmanův překlad Herrmanna a Doroty [...] Kollárův předzpěv $\mathrm{k}$ Slávy Dceři a hojné živly antické v jeho velebásni samé - to všecko ukazuje, že Hollého klasicismus u nás nebyl zjev osamělý" (VLČEK 1903: 253).

4) „Přes svůj formový klassicismus Hollý cítěním i myšlením je velmi blízek slovanské romantice let dvacátých a třicátých, a zejména Kollár, jakkoliv je věkem mladší, jeví se býti Hollého nezbytným předpokladem" (VLČEK 1903: 256). Hollého př́nos ocenil již Josef Jungmann, přičemž kvitoval i klasicistní povahu jeho tvorby: „s podivením a úctou hledíme na toho muže, který snad první ve své vlasti o vyšší básnictví se pokusiti směl, a hned Horacovu lyru v původních odách uchopil, hned za Virgilem, Ovidem i Homérem chvalně pokračoval, a pustiv se sám o svém vesle na epické moře, nového zlatého rouna - Svatoplukyady štastně doplaval“ (JUNGMANN: 36 ). 
v národním duchu. ${ }^{5} \mathrm{~V}$ souladu s tezemi Vladimíra Macury se přisuzuje základní iniciační podnět centru vlasteneckého hnutí, Praze: „nejmocněji však působila na národní uvědomění Vinařického Praha, kam r. 1818 přišel studovat filosofii“ (HANUŠ 1907: 715). K dobru jsou mladému Vinařickému přičtena i dnes nedoložitelná, patrně orální historií zprostředkovaná gesta: jako vychovatel v hraběcí rodině Šliků měl přeložit do němčiny Libušin soud a tento překlad měl být „při výletu na Přemyslově poli u Stadic recitován před četnou aristokratickou společností“ (HANUŠ: 716).

Logika národního příběhu zároveň Hanuše vedla k odlišné hierarchizaci Vinařického díla. Na rozdíl od Vlčka mu nejsou nejpodstatnější Sněmy zvířat, ale pozdní didaktická, dětskému čtenáři určená sbírka Vlast' (1863), v níž „zračí se význam [...] básníka“ (HANUŠ: 716). Stranou tak opět, i když z jiného důvodu, zůstala veškerá umělecky náročná tvorba pro dospělého vzdělance, a to včetně překladů. Především ale převládlo chronologicky vývojové řazení uměleckých směrů jako linie „pokroku“, překonávajícího „zastaralé fáze“, kterou je pro Hanuše klasicismus: „Jen velikou a zaslouženou vážností k národně buditelským, zásluhám [...], významem jeho společenského postavení a virtuosností formální pochopíme dočasný úspěch V-kého básníka. Pěvcem posvěceným patrně nebyl. Jeho význačný sklon ke klasicismu a přežilým formám jeho, př́buzný patrně s jeho zálibou pro filologii, kladení poesie Jana Hollého nad Kollárovu, záliba pro časomíru a nechut $\mathrm{k}$ přízvučnému verši, vrcholící až v nedoceňování Dobrovského a v obranu jeho nízkého odpůrce Stacha [...] dokazují to stejně jako jeho naprosté nepochopení pro moderní směry literární" (HANUŠ: 716-717). Dynamika literárních proměn tak byla redukována na bipolární schéma akce - reakce: „Již básnický vkus V-kého překladatele znamená [...] formálně i ideově reakci, značně ohrožující vývoj novočeské poesie, právě obrozené Máchou a jeho epigony. Nebezpečím ještě větším byly pro tento vývoj vlastní výtvory V-kého básníka a jmenovitě satiry. Jejich ideový obsah a tendence ohrožovaly nejen poesii, ale všechen duševní pokrok v Čechách" (HANUŠ: 717).

Ahistoricky tu byl absolutizován typ poezie, vyhovující výměru moderny a hledající typologického předchůdce $\mathrm{v}$ Máchovi. Vinařický se touto optikou jevil jako „epigon starší generace a poesie vlastenecko klassické“, přičemž „několik svěžejších básní a obrázků přírodních mizí v rýmované próse, v střízlivé

5) Podle Hanuše Vinařický v gymnaziálních letech „sotva četl něco českého, nový ruch v probouzející se literatuře byl mu zcela neznámý“ a „ještě na filosofii v Praze vedl si deník německý“ (HANUŠ: 715). Hanuš si ale zjevně protiřečí, když zmiňuje Vinařického zájem o Hájka, Pelcla a české ochotníky již za gymnaziálních let ve Slaném a zároveň odkazuje na deník z let 1819-1820, v němž mladý Vinařický „objevení každé české knihy zaznamenává jako významnou událost“ (HANUŠ: 715). 
deklamaci, prázdné vší opravdové poesie“ (HANUŠ: 717). Hanuš byl ale kritický i ke Sněmům zvírat, v nichž autor měl dát najevo negativní „poměr [...] k ideám a snahám, unášejícím moderní lidstvo evropské s Francií v čele od veliké revoluce“ (IBID.). Obsah i dikce Hanušova textu jsou klasickým anachronismem a zároveň vaticinatiem ex eventu: slovo moderní implikuje esenciální kvalitu, francouzská revoluce je - v rozporu s podstatnou částí obrozenské kultury - vnímána jako jednoznačně pozitivní historický mezník. Evolucionistické chápání modernosti, svobody, demokracie a humanitních ideálů Vinařickému podsunulo i odpor ke skutečnostem, jichž se ve své básni nedotýkal: „[Vinařický - DaT] pranýřuje nejen [...] stíny moderní této kultury, její industrialismus a materialismus, bezduchý mechanismus sněmování, hlučná, prázdná hesla parlamentní, sobeckost a zištnost poslanců, rostoucí absolutismus, podkupnost a svárlivost žurnalistiky, výstřednosti nové literatury, vědy a umění, brutální germanisaci a mad’arisaci atd., nýbrž stejně pranýřuje také idey nejsvětější, celou moderní emancipaci ducha a člověka, ideální úsilí o svobodu, moderní snahy demokratické i sociální a posléze celý moderní vývoj literární, vědecký, umělecký, technický“ (HANUŠ: 717). Básník se jeví být ve vleku šlechty a kléru, ${ }^{6}$ je etiketován „krajním konservativcem, nesmiřitelným odpůrcem nového ducha, v němž spatřoval jen zlo revoluce, vítězství luzy, anarchii ducha i života“ (IBID.). Sněmy zvírat jsou pak bez argumentů prohlášeny za „dílo, jehož význam tkvěl právě v obsahu a tendencích, nikoli v básnické a umělecké formě, jež pod útlakem hrubé látky a př́kré tendenčnosti všude se bortí, praská [...], přízvučné verše zní místy až barbarsky“ (IBID.). Absolutizace „modernity“ - stejně jako jakýkoli jiný ahistoricky ideologický diskurs - nepřipouštěla mnohoznačnost a vnitřní mnohotvárnost historického faktu.

Hanušův text přitom do krajnosti vyhrocoval argumentační logiku užitou již o dva roky dřive Arne Novákem v syntéze Literatura česká devatenáctého století III/1, a to pod výmluvným názvem Didaktika vstupuje do služeb zpátečnických (NOVÁK 1905: 378-390). I podle Nováka se Vinařického verše „stávají nebezpečím rozvoje literárního, prázdným, ač virtuosním formalismem, úzkostlivým konservativismem, jenž brání se úporně novým duchovním směrům, nicotnou povídavostí, která upadá až v dětinskou žvatlavost“" (NOVÁK 1905: 78). A Sněmy zvírat jsou „přímo pamfletem, zlomyslně namířeným proti novým proudům“ (IBID.: 382). „Tradicionalismus a konzervativismus“ Vinařického Novák vysvětluje zjednodušenou nálepkou kněžského povolání (IBID.: 79). Také umělecká

6) Ty jsou Hanušovi „Kruhy, z nichž hrůza před revolucí dávno zaplašila poslední stopy volnějších, modernějších názorův" (HANUŠ: 717). 
stránka Vianřického poezie byla zhodnocena negativně: „jako básník jeví se Vinařický umělým formalistou, oddaným a učenlivým napodobitelem poezie klasické, nikoliv bez přídechu filologické pedantičnosti a učenecké krátkozrakosti pro skutečné zákony tvưrčího básnictví. Ukázal to dvojím směrem: svým bojem o časomíru i svými básnickými překlady“ (IBID.: 381). ${ }^{7}$ Novák nespecifikoval podstatu onoho „tvưrčího básnictví“, které mu je měřítkem. Pouze nepř́ímo můžeme soudit na subjektivizující principy moderny zlomu století. ${ }^{8}$ Stejně jako Hanuš, projektuje i Novák svá kritéria proti proudu času; klíčovým směrem obrození se pak i jemu stává moderně v lecčems blízká subjektivní romantika a klasicismus je vnímán jako reakční: „je tudíž prosodické úsilí Vinařického pravou klasicistickou reakcí, reakcí právě tak umíněnou jako nebezpečnou“ (NOVÁK 1905: 381). Tvrzení však nelze odvodit analytickou prací ze zkoumaných textů; není ani zřejmé, čím by mohlo být užití určitého prozodického systému „nebezpečné“. Mluvčí se tu vzdaluje od svého materiálu, zaujímá pozici „nad dějinami“ v roli obezřetného a nekompromisního „strážce tradice“ (praveno s titulem jedné Novákovy knihy) - dodejme ovšem pouze tradice jím selektované a absolutizované.

Odvozenost kritérií z disparátního konceptu umění je patrná zejména v obsáhlém komentáři Vinařického versifikace: „znesnadnil si veršovou práci i tím, že napodobil různé strofy antické, že uměle sestrojoval rýmy a veršová schémata. Vady tohoto formalistního fetišismu jsou nasnadě: slovo platí tu více jako zvuk, nikoli však jako znak; zvuková krása řeči odtržena naprosto od krásy výrazové; místo básní jsou to mosaiky libě znějících slov a slabik; obsah jest pouhým pastorkem“ (IBID.: 386-387). ${ }^{9}$ Absolutizace „výrazové krásy“ jako univerzálního hodnotícího

7) I překlady jsou vnímány jako doklad autorova zpátečnictví: „Ani překladatelská činnost Vinařického neznamená pokrok; výběrem i technikou verše se překladatel vrací až k hlediskům Hlasatele Jana Nejedlého. Idylly, heroické epopeje, historické jednotlivosti vzbuzují jeho zvláštní zájem; Vergilius jest autorem jeho srdce; malé ukázky z Horatia střídají se s výňatky z Homera, vlídný selankový úsměv Bionův stále ještě vábí; antikvární výpisky ze Strabona, Tacitova Germania, vzbuzující podiv a závist u slovanských filologů, zasluhují podle jeho úsudku námahy překladatelské“ (NOVÁK 1905: 381-382).

8) Viz především vyjádření „Vinařický nedovede rozeznati rhetorické pseudopoesie od živého, procítěného básnictvi“ (NOVÁK 1905: 382), případně tvrzení, že Vinařského básně jsou „malované pod vlivem idylikův a selankovitých epikův antických, klidnou technikou a bez citového vzrušení“ (NOVÁK 1905: 387). Kritérium „procítěnosti“ přiléhá právě k romantickému a v jeho stopách modernistickému typu básnictví, ale je naprosto nepřiměřené pro posuzování klasicistního modelu poezie, založeného na niterně nezaujaté nápodobě vzorů. Přisouzení kategorických hodnocení „dobrý“ $\mathrm{x}$ „špatný“ v tomto případě předpokládá dvojí myšlenkovou operaci: a) ahistorickou analogii (kladné je to, co je blízké vlastní pozici hodnotícího historika); b) absolutizaci evolucionistické lineárnosti (od původu starší je v porovnání s novějším nutně záporné).

9) Paradoxně se tu Novák k Vinařickému vyslovuje velmi podobně jako známá Tylova kritika pro Nováka vzorného díla, Máchova Máje: Tvar Máchova díla byl pro Tyla „kouzlený automat“, který se ale s přihlédnutím k obsahu odhalí jako „bezživotný, studený, železný stroj“ (cituji podle VAŠÁK: 47). 
kritéria je v důsledku nehistorická. ${ }^{10}$ Novák se jí nezbavil ani po takřka třiceti letech, kdy se $\mathrm{k}$ českému literárnímu klasicismu vrátil $\mathrm{v}$ rámci komentované antologie (NOVÁK 1933). I zde pro něj „básnický jazyk klasicistického období českého zůstává [...] výhradně rétorický a nikde se nepropracovává ani $\mathrm{k}$ hudební melodičnosti, ani k malebné barvitosti“ (NOVÁK 1933: 12). Kritéria jsou tu zjevně odvozena $\mathrm{z}$ romantického, respektive parnasistního typu (především) lyrické poezie. Přesto můžeme v porovnání s náhledy z počátku století registrovat podstatný posun. Kladně se hodnotní např́klad snaha „sestoupiti přímo ke zdrojům antickým“, jevící se v překladech, které „vyvrcholí velkými tlumočnickými činy Jána Hollého a Karla Vinařického“ (NOVÁK 1933: 10). Vinařický tedy již není pomýleně zacíleným a pro svou konzervativnost nepřijatelným překladatelem. Přesto se $z$ jeho textů do výběru nic nedostalo. ${ }^{11}$ Již o několik let později, $v$ rámci své klíčové syntézy, ale Novák psal o Vinařickém ještě jinak, a to bezvýhradně pozitivně. Z básníkových děl je náhle patrný „líbezný duch ušlechtilého kněze“ (NOVÁK 1936-1939: 364), jeho překlady „svědčí [...] o vytříbeném smyslu klasickém“ (IBID.), časopisecké stati o literatuře $z$ let dvacátých až čtyřicátých jsou hodnoceny coby „bystré posudky kritické, zachovávající tradici českého klasicismu“ (IBID.), z beletrie je akcentována sbírka Varito a lyra, v níž autor „ukázal řadou hříček poetických na hudební kvality a libozvučnost češtiny“ (IBID.). ${ }^{12}$ Proměna stanoviska je - pochopitelně - dána změnou optiky. Novák si necení klasicismu více ani méně, převádí jen materiál na jiného společného jmenovatele, než jakým byla na počátku století estetická kritéria moder-

10) Citovanou Novákovu charakteristiku by bylo možno vztáhnout nejen ke klasicistním, ale i k podstatné části parnasistní poezie. Již tato skutečnost potvrzuje spíše vhodnost synopticky pulzujícího, reverzibilního náhledu na proměny literatury, než aby přitakávala představě jejího evolučně lineárního vývoje, založeného na prostém „překonávání“ starších stadií novými.

11) Způsobeno je to zjevně Novákovým konceptem klasicismu, omezeným na dvacátá a třicátá léta („s příznačně a osudově českým opožděním ovládá naše písemnictví v tomto [...] období [...] podněty literární klasicismus“; NOVÁK 1933: 5). Zhruba do poloviny třicátých let je Novákem situován definitivní triumf romantismu („Nerušená a neobmezená vláda romantismu nad duchy v Čechách jest nastolena teprve tenkráte, když vstoupí v popředí literárního života osobnosti, které již neprošly průpravou klasicistickou. Jsou to oba velcí vrstevníci a protichůdci básničtí, Karel Jaromír Erben a Karel Hynek Mácha“ (NOVÁK 1933: 13). Všechny časově následující projevy klasicismu se lineárně vývojovou optikou jeví být nežádoucím opožděním, jak je patrné z hodnocení J. Hollého, „který sám jest pevně věren klasickým vzorům i tvarům ještě v době, když na českém západě zvítězila již romantika nadobro“ (NOVÁK 1933: 6). Klasicismus je zároveň právě citovaným výrokem situovaný extra muram české kultury; připustit jej jako princip intra muram by narušilo myšlenku „západní pokrokovosti“ Čechů a neumožnilo akceptovat tezi naprostého vítězství romantiky ještě před rokem 1840 . Na druhou stranu ale Novák v jednotlivých případech registroval interference romantiky a klasicismu a také vnímal jako klasicistní i významné texty vzniklé ve 40. letech (viz vyjádření „jasný atticismus životní moudrosti v Čelakovského Růži stolisté“; NOVÁK 1933: 10).

12) Nejde přitom jen o posun hodnotící, ale i o kontext, v němž se hodnocení děje a který zároveň spoluutváří. Již užití pojmu „hříčky poetické“ pro dříve zatracovaný prozodický experiment básní Varita a lyry ukazuje pro třicátá léta do sousedství literární avantgardy. Novák tak implicite - a možní i bezděky - vytváří předpoklady k začlenění Vinařického do liniie „progresivní moderní“ literatury. 
ny. Optika je patrná z následujícího úhrnného ocenění: „Jako buditel národní a politický stál K. Vinařický vždy v řadě první“ (IBID.). Mimořádně zajímavé je tu označení „politický buditel“. Může být, a to ještě cum grano salis, vztaženo pouze na jedinou Vinařického skladbu, na dříve radikálně odmítnuté Sněmy zvírat. Proměna Novákových stanovisek ale není dána jiným čtením tohoto textu, nýbrž jiným druhem sekundární operace s ním: místo v důsledku disjunktního pojmu „moderního umění“ se klíčovým pořádajícím rámcem stala všezahrnující, dostředivá „silná idea národní“ (IBID.: 5). ${ }^{13}$

Druhý z podstatných náhledů nalezneme v Dějinách literatury české Jana Jakubce (1929). I pro něj „Vinařický zastupuje na české půdě opozdilý směr klasicistický“ (JAKUBEC 1929: 624). Opozdilost vůči francouzskému či německému klasicismu ale pro Jakubce neimplikovala vývojovou podřadnost ${ }^{14}$; naopak poměrně obsáhle byly registrovány i oceňovány dobová funkce i kladný ohlas Vinařického překladů $\mathrm{z}$ antických literatur. ${ }^{15}$ Ve Vinařického díle zároveň Jakubec shledal interference romantiky a klasicismu, ${ }^{16}$ a to jednak ve snaze vytvořit romantický obraz národního dávnověku, srovnaný výslovně s Kollárem: „Fantastické mytologicko-archeologické utopie Kollárovy se daly rozmnožovat všemi směry. [...] Z učeného materiálu jazykového, archeologického a historického se snažil velmi lopotně, ale marně dokazovat K. Vinařický, že Keltové byli Slované“ (IBID.: 486). I část své poezie Vinařický podle Jakubce skládal s vědomím tvárných norem romantického typu literatury: „formálně mu tanul na mysli

13) Novák přitom ideálem národně a politicky angažovaného básníka korespondoval s ideály První republiky: pro dobu Vinařického se obě složky této charakteristiky navzájem vylučovaly, respektive jejich spojení představovalo nonsens.

14) Ani Vinařického satira nebyla Jakubcem podcenivě odsuzována, ale bez zaujetí komentována: „[Ve Sněmech zvírat Vinařický - DaT] útočil na moderní materialismus a na nové směry v literatuře, zejména na francouzské romány, z kterých se obával potopy na staré ideály mravní“ (JAKUBEC 1929: 627).

15) „Po prvních pokusech o překlad z básnických děl Vergiliových na Slovensku, zejména J. Hollého, a po nedozrálejších pokusech v Čechách od Zieglera, V. A. Svobody a Fr. Šíra, se dal s velkou horlivostí do této práce Vinařický již v letech dvacátých. R. 1828 vyšel jeho překlad Zpěvů pastýřských zároveň s latinským originálem. Jungmannovce zdařilý překlad Vinařického uváděl v nadšení. Byli přesvědčeni, že dávný vzor českých překladatelů, J. H. Voss, byl konečně českým překladatelem dostižen“ (JAKUBEC 1929: 624-625). Jakubec také v porovnání s Hanušem i Novákem registruje obsáhlou a podstatnou vlnu překladů antických autorů i ve třicátých a čtyřicátých letech: „Vinařického neponuklo k urychlení překladu ani to, že jej celým překladem Aeneidy předešel malšický kaplan Josef Rokoš (1800-1874), jako spisovatel neznámý. Rokošův překlad byl již r. 1841 ohlášen v Květech pro Amerlingovu směle pojatou ,Biblioteku klassiků všech národů a časů, věd a umění. Amerling ji s přáteli chtěli vydávat přesto, že zamýšlela Matice česká již od r. 1837 na popud Vinařického vydávat ,Biblioteku cizích klasiků, nových i starých a že pro ni určila Vinařického překlad Vergilia. V Amerlingově ,Bibliotece klassiků‘ vyšly pak v letech 1841 až 1844 české překlady Iliady od Jana Vlčkovského (Vlčka), Františka Douchy Thomsonových počasů, Jakuba Malého Shakespearova Othella a Ant. Lišky prozaický překlad Odyseje“ (JAKUBEC 1929: 625).

16) Jak jsme zmínili výše, vnímal tyto interferenci již Novák, přisuzoval je ale výhradně Palackému, Šafaříkovi, tedy autorům, o nichž mohl pronést klasicismus na okraj odsunující tvrzení „u několika klasicistů českých básnická činnost spadá výhradně do průpravných let jinošských, aby se pak nadobro odmlčela“ (NOVÁK 1933: 10). 
princip umělecké prostoty v lidové písni“ (IBID.: 624). Jakubec přesto nedospěl $\mathrm{k}$ pojetí koexistence klasicismu a romantiky jako bezpříznakového, hodnotově neutrálního historického jevu a snažil se najít svým způsobem omluvné odůvodnění symbiózy „starého“ a „nového“: „Vinařický sám si byl vědom toho, že v době romantismu nebudou čtenáři toužit číst starodávné hexametry. Jen stará myšlenka, že tím, když podá slavného klasika v úhledném českém verši, zvýší u krajanů vážnost k vlastnímu jazyku [...] způsobila, že po usilovné práci r. 1850 mohly vyjít v matiční Bibliotece klassiků Vergilia Marona Spisy básnické, Aeneida, Zpěvy pastýřské a Zpěvy rolnické“ (IBID: 625). Na rozdíl od Hanuše či Nováka ale Jakubec alespoň konstatoval, že „překlad měl velký úspěch“ (IBID.).

Ve druhé polovině dvacátého století se Vinařický - ostatně jako řada dalších autorů doby obrození - dostával stále zřetelněji mimo zorné pole literární historie. V přehledových syntézách o něm nalezneme letmé zmínky (JEŘÁBEK: 192, HAMAN: 83), nebo se jeho jméno nevyskytne vůbec (Janáčková). Důvodem je často nezbytná redukce, soustředěná ke klíčovým bodům literárního kánonu. Zejména v padesátých letech je ale možno vnímat i jinou motivaci: $\mathrm{z}$ marxistického hlediska nebylo přijatelné básníkovo kněžské svěcení a působení ve vysoké hierarchii katolického kléru. Pro svůj kritický konzervativizmus se Vinařický také nemohl stát součástí Nejedlého galerie národních klasiků coby nositelů revolučních tradic. Novákovo a Hanušovo odmítnutí Vinařického ve jménu moderního umění tak bylo replikováno, avšak v jiném kontextu. Společným jmenovatelem zůstalo evoluční pojetí historie. Patrné je to i z argumentace příslušného dílu tzv. akademických dějin, podle nichž: „Vinařický zvrátil ve Varytu a lyře (1843) preromantické úsilí o vytvoření poetické formy v absurdní a titěrný formalismus. Jeho poezie, $v$ níž obnovoval stará preromantická témata, především přírodní idylismus, stojí pod úrovní sentimentální lyriky“ (ŠTĚPÁNEK: 354). $\mathrm{V}$ popředí se následně opět ocitl ideově motivovaný odsudek Vinařického satir, nevedený už ale $\mathrm{z}$ hlediska humanitních ideálů, nýbrž optikou revoluce jako základní dějinné hodnoty: „Ve srovnání s Jablonského didaktickou poezií byla alegorická skladba Sněmy zvírat (1841) církevního hodnostáře Karla Vinařického [...] ve svém konzervativním moralizování mnohem útočnější a tendenčně záměrnější. Projevilo se to i v přímém útoku na Velkou francouzskou revoluci a její odkaz. Nadto byla sbírka umělecky bezmocná“ (IBID.: 361). Až Václav Petrbok opět pohlédl na Vinařického dílo jako na komplexnější a vnitřně dynamičtější jev; zejména se soustředil na interferenci klasicismu a romantiky. Objevně konstatoval oblibu Vinařickým překládaných antikizujících Bionových idyl u preromantiků a poukázal na básnický experiment, s nímž Vinařický na Homérovi 
ověřoval „možnost překládat časoměrným a ,prostonárodním‘ veršem (pětistopým trochejem podle vzoru srbské lidové epiky a RK)“a získané překladatelské zkušenosti „poté uplatnil takřka výlučně u překladu prvního zpěvu Odyssey“ (PETRBOK: 1354).

Dosavadní literárně historická reflexe tedy současnému bádání ponechává poměrně značný prostor. $V$ otázkách diskurzivity přitom neposkytuje obzvláštní oporu a spíše implikuje řadu otevřených otázek.

\section{Vinařického korespondence}

Editovaná korespondence poskytuje možnost nahlédnout do četby Vinařického a jeho korespondenčních partnerů, poznat jejich náhledy na soudobou literaturu, nahlédnout, jak vnímali a vyjadřovali konvergence i izoglosy v rámci dobové tvorby. Podstatné je přitom nejen obsahové, ale i chronologické hledisko. ${ }^{17}$ Nejméně příznakové jsou informace, které můžeme získat o dobovém rozšíření německojazyčné literatury. Tak kolegové z Kopidlna v roce 1823 Vinařického opakovaně žádali o předplacení sebraných spisů Schillerových (KORRESPONDENCE I: 2-3). ${ }^{18}$ Často fungovalo i vzájemné zapůjčování literatury. Například J. J. Langer žádal roku 1831 Vinařického o zprostředkování knih Čelakovskému, přičemž můžeme letmo nahlédnout do pražského antikvárního trhu: „Mám také jeho Herdera: poručí-li juž, hned mu ho odešlu, ač se s ním člověku mně rovnému těžko rozloučiti. Herder jest nyní můj nejmilejší přítel, a kdybych se s ním na věky rozloučiti musil a nevěděl, že ho u každého žida v Praze za peníze dostanu, plakal bych“ (IBID.: 202). Doklady nalezneme nejen pro spontánní znalost knih, ale i časopisů, fungujících zpravidla jako vzory nových českých podniků toho druhu; v tomto smyslu nabádal Vinařický Čelakovského při převzetí redakce České včely: „podávanou vám redakcí novin českých, myslím, abyste přijal. [...] Zdravý med budiž Včely úkol. Ta zastaniž u nás místo přespolního Pfennig-Magazinu“ (KORRESPONDENCI II: 38; 1833). Nalezneme ale i doklady přirozené přítomnosti francouzsky psané produkce a zároveň i existence dalších

17) Pramenem pro následující pasáže je Vinařického editovaná korespondence, uvedená v seznamu literatury. Cituji z ní pouze odkazem na zkrácený titul, příslušný díl a stránku (tedy např. Korrespondence I: 85).

18) Jednalo se zjevně o Friedrichs von Schiller Sämltiche Werke, vydané toho roku v osmi dílech v Lipsku u Fr. Ch. W. Vogela (díly 1-5) a v Stuttgartu a Tübinkách u J. G. Cotty (díly 6-8). 
(byt i méně významných a perspektivních, v daném okamžiku ale přece podstatných) literárních center mimo Prahu: „račte ve jménu mém pana Čelakovského poprositi, kdyby mi mohl karlovarský francouzský almanach ku přečtení zapůjčiti“ (KORRESPONDENCE I: 202). ${ }^{19}$ Zajímavým svědectvím o dobové živosti časově starších textů je dopis, $v$ němž jeden z korespondentů žádal v roce 1833 Vinařického o obstarání Dobrovského literárních časopisů z let 1779 a 1780 (IBID.: 326). ${ }^{20}$

Obzvláště široký rozhled po evropské literatuře a vzdělanosti prokázal Vinařický v rámci svého zájmu o nejranější slovanské dějiny. Jak vyplývá z dopisu adresovaného Čelakovskému a datovaného rokem 1836, byly mu východiskem spisy antických autorů (,já se nyní stále obírám studováním Tacita, Caesara, Strabona“; KORRESPONDENCE II: 233), doplňované ovšem studiem soudobých německých historiografů romantického ražení („spisů Kufahlových, Ludenových atd.“; IBID.). ${ }^{21} \mathrm{~K}$ práci si Vinařický opatřoval i speciální pomůcky, tak „dobrý atlas starého a středověkého světa, zvláště bych rád mapu Peutingerovu, dobré vydání Pliniaa ${ }^{22}$, Ptolemaiaa ${ }^{23}$, a nějaký slovník holandčiny a švábského nářečí“ (KORRESPONDENCE II: 233; 1836), případně Grimmovu Germanii ${ }^{24}$ (IBID.: 238). V průvodním dopise Václavu Hankovi (1838) Vinařický zmínil vrácené jazykovědné příručky švýcarské němčiny, hamburského dialektu, bavorských dialektů a zároveň se pídil po příručkách valonštiny, fríštiny a vlámštiny, respektive doufal snadněji dosíci př́ruček dánštiny a holandštiny, a to vše jako součást zkoumání slovanského původu starých Germánů (IBID.: 296). Se svou

19) Almanach de Carlsbad, ou mélanges médicaux, scientifiques et littéraires, relatifs à ces thermes et au pays pořádal a vydával rytír Jean de Carro. Mezi lety 1831-1856 vyšlo celkem 26 ročníků, publikovaných ponejvíce v Praze u Schönfelda, ale také v Mnichově u Wolfa nebo v Karlových Varech vlastním nákladem. Vinařický do almanachu mezi lety 1831-1854 přispíval přehledem české literatury a část svých statí publikoval i knižně, a to německy, polsky a francouzsky (Über den Gegenzustand der böhmischen Literatur, Praha, Schönfeld 1831; O stanie obecnym literatury czeskiéj, Kraków, Józef Czech 1834; Coup d’oeil sur la Littérature Bohéme de 1836 jusqu a la fin 1840, Praha, s. n. 1841).

20) Jiný z korespondentů informoval Vinařického v roce 1836 o čtvrtém svazku kralické šestidílky (proroci), který je k mání „v židovském tarmarku“, velmi zachovalý „jakoby z impressí teprve přišel“, ptal se, zda V-ký exemplář nechce, navrhoval finanční řešení a doporučoval nezbytnou opatrnost při pořízení „kacířského spisu“: „Protož, jestli snad ten poklad ještě neráčíte míti, a, bych jej koupil, poroučíte, psáti sobě neobtěžujte. Arci, že za ten jediný díl trochu mnoho žádá, ale mně, jak jsem v podobné věci zbrklý, kdybych ho sám neměl, nezdálo by se mnoho. Avšak Kovaň, jestli jen nic neráčíte říci, že jest kniha to in indice male notata, ráda zaplatí" (KORRESPONDENCE II: 185).

21) Patrně se jednalo o tituly Kufahl, Georg Leopold Ludwig: De Saxonum origine et usque at an CDL p. C. rebus gestis dissertatio (1830), Luden, Heinrich: Allgemeine Geschichte der Völker und Staaten (1819 resp. 1824), tentýž: Geschichte des teutschen Volkes I-XII (1825-1837). Luden byl vlivným dobovým autorem a profesorem jenské univerzity, který ve svých přednáškách podnítil k zájmu o dějiny raného středověku i Jana Kollára (viz Tureček: 150-151).

22) Plinius starší: Historia naturalis.

23) Ptolemaios, Klaudios: Geografike hyfegesis.

24) Jednalo se o kometnovaný výbor z Tacita, pořízený Jakobem Grimmem (Germania. Ed. Et quae ad res Germanorum pertinere videntur e reliquo Tacitino opere excerpsit Jacobus Grimm; 1835). 
opovědí mu Hanka zaslal další zásilku knih, zejména neederlandistických a také obzvlášt poptávaný spis Element of Gaelic Grammar vydaný Alexandrem Stewartem v Edinburgu 1812 (IBID.: 297). Vinařický tedy měl velmi specializovaný a vskutku evropský přehled ${ }^{25}$, jakkoli to bylo ve věci, která se zpětnou optikou (a také ve světle pozdější Kollárovy Staroitalie slavjanské z roku 1853) jeví být nevědeckým a ahistorickým voluntarismem. Vyznívají tak i některé Vinařického závěry: „Germanie, Gallie a Britanie před Caesarem obývána byla lidem, který dle obyčejů, zřízení politického, dle náboženství i jazyka nejpodobnější byl potomním Slovanům tak, že v předhistorické době tito předkové Slovanů pod jménem Keltův i Germanů celou střední Evropu zalidňovali, kdežto Němci ještě na severu ve Skadninavii, v Dánsku etc. sídlili, odkudž později na slovanské prabydlitele v Germanii Gallii a Britanii násilně se vrhávali a sídla mezi nimi - bud' po dobrém, nebo po zlém - sobě získali“ (IBID.: 259). ${ }^{26}$ Kognitivním rámcem Vinařického závěrů zjevně byla dobová německá romantická historiografie, ústící do národně vypjatého a literárně hojně reprodukovaného arminiovského mýtu. Výslovná polemika se ztotožňováním moderních Němců se starými Germány a s arminovským mýtem zazněla například v dopise z konce 30. let: „Nelichotím sobě, že má studia mne na světlo přivedou, aniž do sebe té síly Herkulské cítím, abych tento více než Augiův chlév germánské historie vykydati sto byl: než předce snad pomohu nalézti stopu, odkud z této mrákotné houšti Hercinského lesa na stezku přijíti možná“ (KORRESPONDENCE II: 296).

Vinařický tedy $\mathrm{v}$ meritu věci souzněl s dobovými odbornými standardy, ale nebyl nekritický $\mathrm{k}$ romantickému etymologizování. $\mathrm{V}$ jednom $\mathrm{z}$ dopisů $\mathrm{z}$ roku 1838 př́iznačně horoval pro antické autory, které stavěl vysoko nad soudobé zkoumání, směřující „k vysvětlení národních, osobních a zvláště topografických jmen, kterých nám římští a řečtí historikové začasté mnohem přesněji zachovali, než to vidíme v časopisech německých, francouzských a anglických za věku, kde pošty, silnice a dráhy železné i smlouvy králů a národů přístup do všech

25) Vinařický byl dokonce vnímán jako svým způsobem expert na mytický dávnověk Čech, a to mimo okruh českojazyčných vlasteneckých autorů. Svědčí o tom korespondence s Ludvigem Aloisem Johnem, autorem mnohosetstránkového veršovaného eposu o 26 zpěvech Kolostogade, ein Heldengedicht aus den Sagen der čechischen Vorzeit (Prag, Landau 1832). John si u Vinařického upřesňoval možná znění českých jmen svých hrdinů (KORRESPONDENCE I: 12), respektive se dotazoval na staroslovanské bájné bytosti (IBID.: 13).

26) Totožné, v důsledku romanticky ahistorické náhledy Vinařický vyjádřil v úvodním slovu k časopiseckému otisku „Výpisků ze Strabona“" (VINAŘICKÝ 1839). Strabonovy dějiny hodnotil jako obzvláště cenné z hlediska slovanského: „Dílo jeho jest nám Slovanům zvláště důležito. Zvirát v sobě drahé památky o sídlech, činech i mravech našich předků, kteří pode všelikými jmény v dávnověkosti nejen po Evropě, ale i po přední Asii a severní Africe rozššření obývali“ (IBID.: 269). Na základě porovnávacího studia Cesara, Mely, Plinia, Tacita, Ptolemaia následně Vinařický upozornil na „podivný souhlas poloho- a národopisných jmen s podobnými jmény slovanskými“ (IBID.: 269-270), a to ve krajinách za keltické uznaných“ (IBID.: 269). 
zemí evropejských usnadňují. Tacitus a Caesar nežvatlali, o čemž, jak možná, jistých zpráv nenabyli. Na naši historii posud více fantasie než rozum pouhý podíl má“ (IBID.: 296-297). Kromě antiromantického akcentu na rozum proti fantazii stojí za pozornost i pisatelova obeznámenost se západoevropskou žurnalistikou. V tomto kontextu není bez zajímavosti i občasný odstup od některé domácí produkce. V roce 1823 tak Vinařický např́klad zmínil časopis Krok, „který se mi líbiti počal teprve tenkráte, když jsem některý kousek po třetí přečet, nebo ponejprv (musím se $\mathrm{k}$ svému vlastnímu zahanbení přiznati) neporozuměl jsem tomu" (KORRESPONDENCE I: 3-4). Jistý nesoulad s jazykovým konceptem české vědy Jungmannova okruhu přetrval poměrně dlouho dobu; tak ještě v roce 1834 psal jeden z přátel Vinařickému: „Tyto dni jsem nahlédl do ästhetiky Palackého našeho a celé nabyl jistoty, že kdo píše o věcech, kterýmž sám zřeteldně nerozumí, tím samým i zřetedlně o nich psáti nemůže“ (KORRESPONDENCE II: 115).

Vnitřní rozrůznění české literatury Vinařický v korespondenci reflektoval již od prvé polovice dvacátých let. $\mathrm{V}$ roce 1824 polemizoval proti upřednostňování původní produkce před překlady: „Zdaž ale lásku k řeči mateřské své milé prospěšněji neprokážeme snahou, ji také o klenoty cizích jazyků obohatiti, než slepým jich opovrhováním?" (KORRESPONDENCE I: 7). Jednalo se tu o převedení antických textů, jimž byla přisuzována zásadní důležitost pro rozvoj národní literatury: „Dokud Latiníci a ještě lépe Helénové mezi námi se neuvedou, nebudeme skoků činiti“ (IBID.: 66; 1828, Kamarýt Vinařickému). ${ }^{27}$ Jádrem byla otázka, zda „řečtí a latinští klasikové bez újmy svého ducha v slovančinu mohli by být přeloženi“ (KORRESPONDENCE I: 7-8). Vinařický přitom polemizoval s romantickým, citově přepjatým překladatelem, který je „slepým horlivcem“ a předlohu volí „temným veden citem“, zatímco náležitý přístup má být určen „světlým přesvědčením“ (IBID.: 7). Předmětem debaty se stávaly i technické problémy převodu antických textů. Tak v roce 1828 Vinařický v polemice s Macháčkovým požadavkem přízvučného přebásnění zpochybňoval umělecký efekt takového překladu a zároveň registroval napětí mezi versifikací a deklamací: „Proč ale překládáme staré? Abychom cítili krásu jejich básní; jak ji ale můžeme cítit, když jejich básně dle jejich způsobu nezpíváme?“ (IBID.: 92). Táž klasicizující kritéria užil i při porovnání děl Kollára a Hollého; do protikladu přitom

27) Dokladů preference antické klasiky nalezneme ve Vinařického korespondenci povícero; jako pars pro toto citujme jen jednu pasáž z dopisu F. Vacka: „podělte, prosím, Čechy naše, s častým přeložením klassiků latinských, následuje v tom našich přeslavných předků, kteří tak chvalně zanášeli se literaturou řeckou a latinskou, kteráž pak po několika století naprosto byla zanedbána. Jak mnoho musila by naše literatura česká vyzískati, kdyby více učených Čechů s takovoužto literní znášeli se prací!“ (KORRESPONDENCE I: 205) 
postavil žádoucí „jasnost a čistotu idey“ či „objektivnost“ proti zavrhované „vášnivosti“. ${ }^{28}$

Korespondence přesvědčivě dokládá intenzivní recepci překladů z antiky v rámci přátelského okruhu Vinařického. Tak plzeňský Vojtěch Sedláček v roce 1828 děkoval „za utěšené Vaše přeložení Zpěvů pastýřských Vigilových srdečně, kterými zaplesala nad míru duše má. Mistrná to práce! Bůh Vás posilň a osvit,, abyste zmužile a dále $\mathrm{v}$ překládání i ostatních prací Maronových štastně pokračoval, bychom brzy i Bukolika a Aeneidu od Vás české uzřeli - a pak na Homéra se oddejte“ (IBID.: 63). Jak svědčí jeden z listů knížete Kinského z roku 1831, existoval počátkem třicátých dokonce jistý kult Vinařického jako překladatele z antiky: „Všickni se divíme ohebnosti a skladnosti [Vašich - DaT] veršů (co jsou proti nim vychválení Vossovi -?), všickni mistrovskému překládání Virgila, Horáce, Lobkovice. Jak to nenuceně a čistě plyne, jak verš se smyslem se srovnává, jaká pochotnost ve všem, čehož se péro Vaše dotkne!“ (IBID.: 215). Kladný ohlas dokládá korespondence po celá třicátá léta především pro kněžské a šlechtické kruhy: „Selanka Vaše [...] mne nanejvýš blažila. Kdyby znatel byl, záleželo by Vám na pochvale té mistrovské práce. Zatím mohu říci, že ji čtu a nasytiti se nemohu. Přicházít mi jako klidný, tichý večer za nejdelších letních dnů, kdy slunce dávno zašlé, přec jasnost svou ohřívající na celou přírodu posílati nepřestává. Tak se líbila, kdo ji koliv u mne četl. Pan Hrabě Kolovrat prý si ji častěji mezi obědem čítati dává“ (IBID.: 329; 1833). Poměr k antice mohl být dokonce základním rozlišujícím kritériem literární kvality, a to ještě v roce 1835 , kdy již publikovali či tvořili autoři romantického typu jako Mácha, Sabina, Erben či Tyl; dokladem je výrok pomíjející zcela všechny právě jmenované a dnes kanonické autory: „mezi mladíky výhradně p. Vlček, co překladatel Homerovy Iliady, se skví" (KORRESPONDENCE II: 138). Stejně samozřejmá byla v dopisech i frazeologie, vyrůstající z antických dějin a mytologie; tak kolega za studií bohosloví Faehnrich povzbuzoval Vinařického: „Bojuj tedy v Thermopylách, padneš-li, padni se ctí “ (KORRESPONDENCE I: 22; 1825). Nalezneme i pro nás komické mísení antické vzdělanosti s lidovou frazeologií; jeden z přátel děkoval Vinařickému za elegii k nastolení do funkce sufragána a dodal: „Nebyl bych sice s to Vám ke cti pastýřskou složiti píseň, neb družka Apollinova [...] usmívala se

28) „Vím sice, že Holého Svatopluk odsouzen jest a zahozen u nás: než věru my nemáme básníka českého takového, jako Holý jest. Já jej kladu nad Kollára. Tento nepojal idey člověčenstva tak čistě a jasně, jak ji Holý postihnul. Onen jest vášnivý a často nespravedlivý, tento tichý a vždy nestranný v úsudcích svých. Holý pojal dokonale objektivnost nevyrovnaného Homéra“ (KORRESPONDENCE II: 217; 1836). 
někdy laskavě na mne, nyní však na starce [...] jen prdelí se obracuje“ (IBID.: 325; 1833).

Pro nás jsou ale zajímavější doklady interakce různých typů literárnosti. Dopis J. J. Langera z roku 1833 Vinařickému objasňoval vznik sbírky Selanky (1830): „V roce 1828 a 1829 [...] skoro všecko psal jsem časoměrně a uhodě v básni několik po vlastenecku znějících jmen a bohů, myslil jsem, že již také píši národně. Na konci roku 1829 se mi však časoměra tak zošklivila, že sem nade vším klatbu vyřkl, do kouta vše odhodil a selanky v prostomluvě, psané nejvíce $s$ písněmi přízvučnými neb toliko na prsty počítanými z prachu vyhrabal a již v roce 1830 vydal. Avšak že málo jich býti zdálo, smiloval jsem se nad některými časoměrnými a vmísil jsem je mezi ně. [...] Kam se mi zavržené hexametry a pentametry poděly, nevím. Vložil jsem je mezi nepotřebné papíry, a tudíž s nimi zahynuly. Prohlížeje nedávno drobnosti, co moje matka dává pod koláče, nalezl jsem jednu z těch zavržencův" (IBID.: 312-313). Plynule překračované rozhraní mezi klasicistním a neklasicistním typem literatury, projevující se $\mathrm{v}$ příklonu $\mathrm{k}$ příslušnému typu versifikace, tedy bylo ještě v konci dvacátých let pro začínajícího ambiciózního básníka samozřejmou volbou. Langerovy řádky tak jasně dokládají způsob existence živé kultury jako různorodého, často jen intuitivně či prostřednictvím náhody motivovaného pulzačního pohybu v poli dobových literárních možností.

V silovém poli různorodých diskurzů se ale ocital i Vinařický, platící jinak pro literární historii i pro okruh svých současníků za vzorného českého klasicistu. Markery vlastenecké romantiky zřetelně vysvítají z obsahu i dikce dopisu, datovaného rokem 1828: „Aj zdá se mi, že lid náš nesmě rozmlouvati v jazyku svém se světem vznešeným, za to rozmlouvá se vznešenou př́rodou, a $z$ těch zdravějších pramenů čerpávaje slast a útěchu jistější a trvalejší, než ji cizozemským mravem olíčené besedy poskytují“ (IBID.: 83-84). Podstatnou izoglosou se optikou Vinařického korespondence jeví být rozhraní umělecky náročné tvorby a konvenčního lidového čtení: „Vyšší umění se sice v mateřštině vzmáhá, což ovšem potěšitelné, ale pro lid málo doposavad činěno. Dokud knihy české od národu veskrz i těch nejsprostějších nebudou čítány, literatura naše se nepozdvihne. Aby se ale toho cíle došlo, musili by se mnozí naši spisovatelé teprv od lidu sprostého učiti a k němu do školy choditi, by se srozumitelnosti naučili“ (IBID.: 114, 1829). V témže duchu, navíc s ohledem na svízele knižního trhu, psal v roce 1830 Vinařickému i Kamarýt: „Chuti ke čtení ovšem den ode dne přibývá, co se školy trochu zvelebovati počínají a co se mládeži praví, že se neučí číst jen pro kalendář a pro modlicí knihu. Však to také víme, jak bídy mezi obecným lidem 
pořáde přibývá a že při nejlepší vưli a schopnosti mnohý člověk nemůže sobě dobrou knihu koupiti. A při malém odbytu nemožno spisovateli zvláště na cos většího a důležitějšího náklad vésti, tedy vše stojí - bud' leží ladem“(IBID.: 171). V korespondenci z roku 1836 probleskne i snaha o založení nakonec neuskutečněného časopisu pro lidové vrstvy Nový lidomil. Navržen byl program, obsah na první ročník, zváženo financování, vyhlédnuta tiskárna. Vinařický Chmelenskému upřesnil i stylové požadavky: „Všecko ovšem musí býti psáno slohem prostonárodním, jak to u př. Kramerius starší uměl. Jinak nedostane [...] přístup mezi lid“ (KORRESPONDENCE II: 229-230). Redaktorstvím podniku byl obmyšlen Čelakovský, ale ani on, jakkoli zejména ve školské literární výchově reprezentuje „lidové křídlo“ obrozenského projektu, nebyl Chmelenskému či Vinařickému vhodným typem vskutku „lidového autora“: „Umímt ovšem dobře oceniti tohoto muže veliké dary; ale proto se přec domnívám, že by snad za dobrými příčinami ještě lepší volení státi se mohlo. Čelakovský se vidí v každém ohledu k vyššímu oboru literatury povolán býti, [...] nevím, zdali s povahami našeho sprostého, vesního lidu dosti seznámen; an se $\mathrm{z}$ mládí jen $\mathrm{v}$ městech pohyboval“" (IBID.: 221-222). Ačkoli se ve třicátých letech projekt neuskutečnil, nahlédli jsme tu alespoň do motivace pozdějšího odklonu Vinařického od vysoké poezie ve prospěch veršování pro děti a mládež.

Od roku 1835 vystupuje $\mathrm{v}$ rámci korespondence výrazně do popředí další izoglosa, striktně vymezující jednoznačně negativně vnímanou subjektivní romantiku. ̌̌adu argumentů snesl Prokop Ondrák, o málo později překladatel Manzoniho románu I Promessi Sposi. ${ }^{29}$ V roce 1835 Ondrák satirizoval Tylovy Květy, mezi jejichž přispěvateli výslovně uvedl Máchu: „Čechové nyní chtějí mít všecko živé [...]. A jaký že může být spisovatel živější, nežli třináctileté pachole, které sněhem ještě po lidech hází, se pere a živostí neví, co dělati. Protož [...] jenom až do třináctého roku připuštěn u mne bude skladatel, co nad ten věk, nebude přijato. Jaká to zpozdilost, teprv v šestnáctém, sedmnáctém atd. roku průchod dáti spisovatelskému svrabu, kde již logika, fysika a jiné školy z člověka život ssají. Nemyslete, že snad budu tak malicherný jako jiní redaktoři, abych na gramatiku, sloh, logiku atd. hleděl; kdo na takové tintěrky pozor dává, nezná vkus našich nejmladších spisovatelů. Učení nepotřebují moji spolupracovníci býti, ale zato tím drzejší; kdo z nich nebude uměti nadávat jako drvoštěp a jako valchař zasloužilé muže kritisovati, na věky bude vyloučen. Kohož práce svou živostí (= třeštěností) nejvíce se zalíbí, tohož podobizna bude vykreslena 
[...]. Každému z mých autorů bude volno proti svému učiteli, od kohož pardus dostal, kritiku psáti. Látky budou brány z čítanek a slabikářů a každodenního života těchto literatorů. [...] Někdy také přidám půl archu s oznámením, jaké literární plody můžeme očekávati od toho onohože chlapce, třeba by pravdy nebylo“ (IBID.: 122). Charakteristický tu je výslovný protiklad vyzrálosti, formované (klasicistním) vzděláním a spontánní romantické seberealizace, označené ironicky dokonce jako „svrab“ (IBID.). Odpor k Tylovým Květům vyjadřoval Ondrák opakovaně, přičemž ironizoval stylovou nejednotnost a především přepjatou ambici podle něj nedostudovaných, tedy nekompetentních mladých autorů: „Květy jsou skutečně květy bílé, červené, zelené, žluté atd., od samých studentů, nejvíce logiků a fysiků vyrobené“ (IBID.: 138, 1835). ${ }^{30} \mathrm{~V}$ témže roce Ondrák ironizoval i jeden z možných pretextů českého subjektivního romantismu, Youngovo Kvílení noční, vydané v překladu Nejedlého roku $1820^{31}$ : „Vaněk to jmenuje kvičení a břečtění" (IBID.: 130).

Vinařický sám nebyl přítelem literárních polemik, ${ }^{32}$ proto v jeho dopisech nalezneme jen málo útoků na romantiku, která je ale v oněch ojedinělých případech př́iznačně stavěna do protikladu $\mathrm{k}$ antice a ironizována: „Hansgirg ${ }^{33}$ píše o romantice? / Hrob li vykopán již již antice? / K hotové té komedii / Tyl by neměl titulu, / To patři do John-Bullu. / [...] Stavěti-li má se radnice / jako kostel ghoticky?" (IBID.: 235). Nejobsáhleji Vinařický komentoval napětí klasiky a romantiky v dopise Chmelenskému z roku 1837: „Ulehlá půda literatury naší nejštastněji vzdělati se dá překlady z klassiků starých. Nejsem slepý nepřítel subjektivního básnictví romantického: ale nikdo mne nepřemluví, že u př. slavné výtvory lorda Byrona podobné byt by sebe podivnější záře a omamující ohnivé páry noční - tak spanilé jsou jako ono věčné slunce a hvězdy dávné osvěty čisto-člověcké. Nejspíše také naše mládež studující k zamilování materštiny se probudí, dostane-li v dobrých překladech klassiků nejpatrnějších důkazů, že řeč vlast naší nad jiné

30) V tomto kontextu zřejmě získávalo podstatný - negativně vnímaný - význam i Máchovo gesto, s nímž na frontispis prvního vydání Máje vepsal „Spisy Karla Hynka Máchy. Díl první. Svazek první“. Autor několika málo publikovaných textů tak ve své první knize sugeroval rozsah a význam svého díla, který by se v té době dal přirovnat snad k tvorbě Goethově či Schillerově a v domácím kontextu by neměl zřetelnější obdoby.

31) Edvarda Younga Kvílení aneb Rozjímání Noční, z anglického jazyka přeložené do českého od Jana Nejedlého. Praha, K. Widtmann 1820.

32) Ve veršovaném novoročním dopise Chmelenskému z roku 1838 horlil proti veřejným polemikám českých spisovatelů, ironizoval jejich časopisecké půtky a nabádal k nestrannosti a nadhledu (KORRESPONDENCE II: 269-270).

33) Etnický Němec Antonín Hansgirg (1806-1877) byl od svých univerzitních studií v Praze (absolvoval jako jurista r. 1829) v kontaktu s Jungmannem, Hankou, Čelakovským, Koubkem či Vackem Kamenickým. Pod jejich vlivem přispíval v třicátých letech do časopisů Česká včela a Ost und West a překládal z ruštiny i polštiny. Vinařického narážka se patrně týká některého $\mathrm{z}$ jeho časopisecky uveřejněných př́ispěvků. 
evropejské předčí, totiž svým nevyrovnaným organismem, který ctnosti starých jazyků zahrnuje. Toto poznání mě alespoň poskytuje vždy rozkoš nadobyčejnou. Vydávání klassiků musíme tedy na mysli a péči míti“ (IBID.: 236). Následně Vinařický předestřel poměrně podrobný plán edice antických překladů, včetně jejího autorského, nakladatelského, redakčního a finančního zajištění, předplatitelské strategie i časového plánu. ${ }^{34}$ Nakonec sice zůstalo u výhledu a Vinařický svou část práce otiskl samostatně v padesátých letech ${ }^{35}$; přesto se jedná o doklad velmi konzistentní klasicistní koncepce české literatury k roku 1837. Její dobová funkce byla určována romantickým a protiromantickým vřením poloviny třicátých let a český klasicismus tu nutně nabýval jiných hodnot, než ve svých prvních vlnách od konce 18. století nebo v letech dvacátých.

Produktivní ale i nadále zůstávaly interference s vlasteneckou romantikou: $\mathrm{v}$ hexametry psaném dopise z roku 1838 Vinařický zcela v bukolickém duchu chválil Chmelenskému své působiště, a zároveň s pozváním sliboval, že hostu budou místní vypravovat fantastické místní pověsti. ${ }^{36}$ Byl si přitom vědom

34) „Vyjevím Vám zde o tom své smýšlení. Vím, že prof. Macháček i prof. Chmela klassiky se obírají; Čelakovský svým Martialem také pohybuje; a proč by Chmelenský měl nenáviděti svých starých známých a miláčků? Mám též naději, že pilný Vlček svou Iliadu tak připraví, aby se vůbec zalíbili mohla. [...] Macháček pracuje na Ciceronovi, na výboru básnických listů a satir Horatiových. Chmela dej nám Livia a Plinia, Čelakovský kvítí z Martiala, Chmelenský Tibulla, Cornelia Nepota a Suetonia, Vlček Iliadu a Odysseu, já se o Virgila, kvítí z Horatiových ód a Julia Caesara pokusím. Všickni se zavažme uživati slohu pouze českého, jasného, srozumitelného. Co se s ušlechtilostí mravů nesrovnává, nepředloži se, aby knížky ty bez rozpaků mládeži poroučeti daly. Jeden po druhém podávejme práce své na 6 tištěných archů dostatečné. Poesie střídej se s prosou u př. svazek I. počátky Aeneidy, II. z Cicerona, III. počátek Iliady, IV. Tacitus, V. Tibulius a kvítí z Horatia, VI. Titus Livius, VII. pokračování Aeneidy neb Iliady, VIII. Cicerona atd. Strany se číslují pravidlem věcí k sobě náležejících. Rozmanitostí takovou vyhovíme odběratelům. Čelakovský vezmi na sebe redakci a dohled tisku. [...] A kdož povede náklad? Jednejme s Webrem o to aneb s kýmkoli jiným přičinlivým knihkupcem. Dílo to cestou předplatní vycházej, dle mínění mého ve svazcích šestiarchových měsíčně; cena svazku na pěkném papíře za 25 kr., na sprostějším ale vždy dobrém za 20 kr. stř. Předplacení přijímej se nejméně na čtvrtletí. Kdo jednotivé svazky zvláště méto chce, připlat’ 20 procent. Honorář spisovatelův ustanov se dle slušného uznání nakladatelova vzhledem na poesii a prosu; pro redaktora vymiň se zvláštní odměna. Ale což nesejde-li se potřebný počet praenumerantů na zapravení útrat? Nepočneme ničeho, vidouce v tom znamení, že Čechové o klassiky nestojí. Zatím ale potřebí umluviti se a práci počíti, by vina nelpěla na nás. Po úmluvě učiněno bud’ prohlášení a pozvání k prenumeraci do září t. r. trvající, pak uvidíme, smíme-li co podniknouti“ (KORRESPONDENCE II: 236-237).

35) Latenci přitom nemůžeme přímočaře chápat jako případný doklad neperspektivnosti, „vývojové opožděnosti“ podniku: kdyby romanticky orientovaní spisovatelé přišli v téže době s analogickým podnikem, zůstal by s největší pravděpodobností také nerealizován. Dokladem je ostatně dopis Turinského Vinařickému z roku 1840. Plánoval v něm nakonec nerealizovaný almanach, který by vycházel od roku 1841. Charakter byl romantický, beletristická část měla obsahovat především „epické básně z historie slovanské. Pověsti slovanské dávnověkosti v rouchu romantiky“, které měly doplňovat „Krátké články humoristické. Nevelká činohra neb veselohra aneb dramatické scény ze života slovanského. Národní obyčejové, starobylé zvyky a mravy, anekdoty důvtipné, národní písně (s nápěvy) a báje na mythologii slovanskou a hrdinské činy se vztahující. Cesty po Slovansku. Způsoby a kroj tamního lidu mužského i ženského pohlaví“ (KORRESPONDENCE II: 329-330) I zde byly detailně navrženy technikálie (termíny, honoráře), spekulovalo se na „odbyt mezi lidem, duchovenstvem a šlechtou“ (IBID.: 330).

36) „Ku kratochvíli také bude Tobě povídati soused / O svěcených pramenech a pohádky o prádle Poludnic“ (KORRESPONDENCE II: 307). 
synoptické povahy kultury, jež ho obklopovala: „Klassická naše jest vábnou pro romantiku půda“ (IBID.: 307). Po roce 1848 nabyl klasicismus novou funkci útěku před společenskou a politickou realitou. Roku 1850 jeden z přátel Vinařického skepticky hodnotil nedávné události, jež pro něj byly „krev marná a naši vlast z nerozumu vinící", a v závěru pojmenoval jako východisko literární tvorbu v klasicistním duchu: Kdyby se Praha uchovala před tím klesnutím, byla by v mocnářství se stkvěla co neporušená převratem myslí, [...] tak ale slabost českého národu se vyjevila a obležení jest dosavadní památkou na nehodu té doby. Sladkovský a jiní nejvíce škodili. [...] Ti neštastní demokraté Pražanům hlavu zmátli [...] Děkuji za lidovládu - já ji málo zkusil, ale dost jsem toho měl, když každý chtěl poroučet, každý vůli svou za zákon držel posvátný, každý jen vášnivosti své se oddával. Vím, žes byl rád, když jsi Vídeň, pak Kroměříž opustil - nyní sedíš na Parnase a svět mizí pod výší tou - s Virgilem a zbožným Aeneášem proplavuješ moře a pocestuješ dálné časy a krajiny. - Na koníku šestinohém se projíždiš vesele a krásná caesura Tě potěší víc, než hrouda zlata nalezená lakomou rukou v bohaté Kalifornii. - Kdo žije v říši ideálů, ten jedině blaženě žije. Já také žiji nad tím slzavým údolím ve výši blahé“ (KORRESPONDENCE III: 27-28). Za zdůraznění stojí výslovný odpor proti „vášnivosti“ revolučních aktérů. Antika pak získala novou kvalitu svou zdánlivou idylickou vyrovnaností, sugerovanou optickým klamem časové odlehlosti.

Klasicismus $\mathrm{v}$ nových poměrech a s novými funkcemi přicházel spontánně ke slovu jako soukromá přiležitostná poezie v rámci dopisů (viz kupř. IBID.: 188-189, 1854). I tak renomovaný, ba alespoň částí literární obce uctívaný autor, jakým v počátku padesátých let Vinařický byl ${ }^{37}$, ale jevil skepsi k širším možnostem klasicistní poezie na veřejném fóru. Dokladem je odpověd’ redaktorovi almanachu Perly české (1855), Antonínu Jaroslavu Vrtátkovi, na jeho prosbu o zaslání příspěvku: „Čestnému vyzvání Vašemu [...] vyhověti nemohu. Antické formy nejsou po chuti novému věku, a rýmem vládnouti neumím“ (IBID.: 181-182). Od padesátých let se Také Vinařického korespondence takřka bez výjimky soustředila k otázkám školství a čítanek, respektive k rodinným či katolicky hierarchickým záležitostem. Prestižní beletrie z ní takřka naprosto zmizela, včetně nových edic Slávy Dcery, $R K Z$, české verze Palackého dějin, ale i děl Němcové, Erbena či nastupujících májovců.

37) Viz oslovení „Proslulý veterane naší literatury“v Amerlingově dopisu z roku 1854 (KORRESPONDENCE III: 190). 


\section{Vinařického beletristické práce a texty beletrii věnované}

\section{A) Metařě}

Vinařický po řadu let komentoval českou literaturu pro francouzsky psaný karlovarský de Carův almanach. ${ }^{38}$ Dvojí knižní vydání (polské 1834 a francouzské 1841) zpřístupnilo jeho náhledy širší veřejnosti. Povaha literárního přehledu vedla k registrování literární produkce ve velké šíri. Jako doklad vysokého stupně rozvoje češtiny již v 8. století Vinařický cenil Rukopis královédvorský (VINAŘICKÝ 1834: 4). Za příkladné dílo české literatury považoval ve třicátých létech Kollárovu Slávy dceru, kterou stavěl na roveň kanonickým autorům minulosti: „Kollár jest Petrakrą swego narodu“ (IBID.: 15). Není bohužel jasné, které rysy či vrstvy Kollárova díla Vinařický oceňoval. Přesto z jeho soudů prosvítá diferencovaný poměr $\mathrm{k}$ různým typům psaní. Polákově Vznešenosti kupříkladu vytýkal odchylku od klasicistní versifikace: místo osmistopého trocheje by býval měl autor užít hexametr a při trochu zdařilejší tvorbě poetismů mohl být na úrovni „zagranicznych tego rozdaju utworów“ (IBID.: 15). Již roku 1829 také požadoval $\mathrm{v}$ implicitní polemice proti romanticky emocionálnímu pojetí národního jazyka upřednostnění rozumu: „Národ, jenž nedbá o jazyk svůj, dbáti nemůže / též o rozum: s obojím na bludu ještě vězí. / Vždycky jazyk s rozumem jdou pospolu k vycvičenosti, / jen že rozum na před, pak mu jazyk pomáhá“ (VINǍ̌ICKÝ 1829b: 82).

O deset let později byly Vinařického náhledy vyprofilovanější a osobitější. Přehled poezie například v roce 1841 nezačal původními texty, ale překlady, především $z$ antických autorů: klíčové hodnoty tedy pro něj nespočívaly - jak by tomu bylo u romantiků - v původnosti, ale v klasicistním duchu je spatřoval ve schopnosti imitace či nápodoby. Literární kánon se mu pak jevil jinak, než jak jej pro třicátá léta a pro počátek následujícího desetiletí později stanovila literární historie: „Dans le domaine de la poésie, nous a signalos les excellents sonnets de Kačer, les poèmes de Macháček, les ballades de Trojan et de Šohay. Nous devons à ce dernier une bonne version du IV livre des Gorgiques de Virgile. Les beaux distiques de Vacek Kamenický, dans ses Élégies sur la tombe d' une mère, rivalisent d'harmonie avec le rythme grec. Nous trouvons encore 30 sonnets de Pétrarque, par le même auteur; Ines de Castro, episode de la Lusiade, du Camoens, par Pichl; dix chansons anacréontiques par Chmelenský; trois fragments des

38) Viz zde poznámku č. 13. 
Saisons de Thomson, et des chansos populaires de la Lusace par Doucha" (VINAŘICKÝ 1841: 4-5).

Mimo pozornost nezůstal ani romantický typ literatury. Vinařický jej spojil především s Tylovými Květy, v nichž „Sabina et Wrtátko ont arboré la bannière du romantisme“" (IBID.: 17). V této souvislosti upozornil i na Denici J. B. Malého, která v roce 1840 přinesla výtah z románu A. Dumase Fiacre, jehož motivy (atentát, souboj, sebevražda) podle Vinařického cílí na "le système nerveux“ (IBID.: 17). Frenetická produkce měla najít v české literatuře napodobitele, ale sám Malý polevil v uveřejňování „ces horreurs“ (IBID.: 18); v jednom ze svých pojednání ale Malý akcentoval rozpor ideálu a reality jako základ moderního typu literatury, čímž „caractrise avec force le romantisme français“ (IBID.). Proti tomu Vinařický zdůraznil (zjevně klasicistický) „le point central de la vraie poésie“ (IBID.: 20), který se vylučuje se sférou romantismu, jelikož „Nous pensons, au contraire, que le type de la vraie poésie doit être l'harmonie entre l'idéal et le réel“ (IBID.: 19). Romantika mu následně byla „la parodie et le dégoûtant reflet du beau, et très-souvent du bon“ a její „la nouvelle école“ pouhým „nébuleux météore“ (IBID.: 20). Okrajově, ale příznačně Vinařický komentoval centrální text českého subjektivního romantismu, Máchův Máj, který mu byl „une sensation extraordinaire“ (IBID.: 25), přičemž senzačnosti byla v rozporu s klasicistní uměřeností přisuzována jednoznačně záporná hodnota. ${ }^{39}$ Zvláště pak Vinařický upozornil na kriminální motivy Vilémovy sebereflexe, kterou označil za „le faible philosophisme de ce froid scélérat“ (IBID.). Mácha mu byl „digne disciple de Byron“ a charakteristickou pasáží mu byla noční „sérénade fantastique“ (patrně první intermezzo, IBID.). Poetiku Máje úhrnně charakterizoval jako „nébuleuse imagination“ (IBID.: 26). Romantickou povahu podle něj vykazovala i básnická sbírka Smíšené básně (1836) F. V. Rába (1804-1838), kterou s odkazem na možný pretext označil za „L'écho de la muse mélancolique de Matthison“ (IBID.: 27).

Klasicistní koncept se nejpatrněji manifestoval ve sporech o prozódii, jichž se Vinařický účastnil od konce dvacátých let. ${ }^{40}$ Podstatným podnětem pro něj byl pobyt ve Vídni, ${ }^{41}$ kde byl přijat Kopitarem a zejména se setkal s propagátorem časomíry Václavem Stachem ${ }^{42}$, který mu dal knihy a rukopisy odpírající př́izvu-

39) Vinařický přitom registroval kladná hodnocení Máje z pera Vlčka, Kuzmányho, Sabiny a Riegra (VINAŘICKÝ 1841 : 26).

40) Nejde nám tu o úhrnnou problematiku prozodických sporů, ale o Vinařického stanoviska, dokládající klasicistní povahu jeho náhledů a zpo̊sob jejich manifestace.

41) V letech 1820-1821 tam studoval třetí rok filozofie.

42) Václav Stach (1754-1831), působil jako profesor pastorální teologie v Hradisku u Olomouce, publikoval v Thámových básnických almanaších, 1820 odešel do vídeňského kláštera sv. Michaela; 1805 vydal Starého veršovce 
ku a plédující za antické vzory ${ }^{43}$ (VINAŘICKÝ 1829a: 76). O sylabotónii Vinařický následně psal jako o „nové svévolné versifikaci, podle níž se všecko co verš měřiti dá" (IBID.: 80). Argumentem pro časomíru mu bylo i její užití starými Čechy - uvedl Blahoslava, Drachovského, Komenského a Rosu, v jejichž poezii „verše vidíš [...] v lehkonohém se zatáčeti tanci“ (VINAŘICKÝ 1830: 51). Návrat k časomíře mu v narážce na Dobrovského stat Böhmische prosodie byl osvobozením verše, „jenž dlouho jak otrok spoután byl jalovou Grammatiků reguli““ (IBID.: 52) ${ }^{44}$ Sylabotónismus zároveň odmítl jako domněle od původu německou záležitost, ${ }^{45}$ jako „nález cizozemstva lichý“, verš, který „mysliti Němce nechá“ (IBID.). Jeho argumenty tu souzněly se staršími náhledy Počátkủ. Zároveň ale sylabotónismu neprávem vytýkal nedostatek tvárné kázně, když „tancuje,

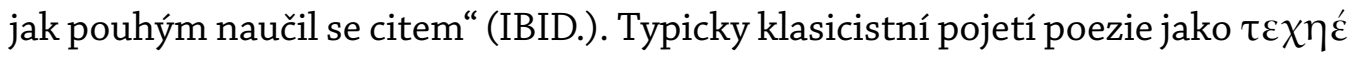
Vinařický dále rozvedl výkladem možností skládání disticha, přičemž navrhoval i apokopy typu „charpa“ místo „chrpa“ (IBID.: 53). Takových příznakových momentů je ale podle něj potřeba šetřit, zato se spolehnout na přirozené bohatství češtiny, která podle něj k časomíře lne ze své podstaty: „Kdož takové jazyku schopy dal? Sama příroda, cit náš“ (IBID.: 54). Následně „líbeznou lahodí spanilá uchu Čeština hudbou, / v taktu se hellenském lehce a volně točí“ (IBID.: 56) ${ }^{46}$ Jedním z příznaků domněle pokleslé sylabotónické poezie se stal rým. Nerýmovanou časomíru Vinařický přirovnal ke vznešeně pějící bílé labuti, zatímco sylabotónické „ptactvo nečisté“ závistivě kráká „v rýmech kostrbatých“ (VINAŘICKÝ 1830: 55). Vinařický tu navazoval na argumenty Šafaříka, který také proti helénské normě postavil barbarské národy, jejichž řeč nedovolila básnit podle

pro rozumnou kratochvíli, spis polemicky zaměřený proti Dobrovského a Puchmajerově sylabotónické prozodické reformě.

43) Podle vlastního tvrzení Vinařický měl u jednoho z vídeňských antikvár̆ů zachránit Stachův rukopis Harmonie a dobrozvučnost jazyka českého, kritickým přirovnáním německého, řeckého a latinského s ohledem na prozodickou povahu jejich vyložená, ode všech matenic nejnovějšího veršovství osvobozená a rozmanitými príklady vyjádřená (VINAŘICKÝ 1829a: 79).

44) Oproti tomu Puchmajer vzrušeně polemizoval proti časomíře a zastával se Dobrovského pravidel; v patetickém a ironizujícím výpadu psal o českých básnících, kteří „posvátnou přízvuku archou opovrhše, pozicí za modlu vystavili; jest ale naděje, a nesmrtelný vypatratel přízvuku, jemuž řeč naše své vzkříšení, a tím samým základ svého nynějšího prokvítání a naději budoucí záře povinna jest, snad ještě se dočká, že tento nový Jázon, světla a pravdy snésti nemoha, s trůnu se skácí a roztroskotá; nebot’ co na písku se staví, sesuje a zboří se. Pozicí některým mladším básníkům, příkladem pár slavných jmen svedeným, vrtí mozek; ale Hněvkovský, zkušený lékař, předepisuje proti tomuto neduhu prospěšné líky, zvlášt̉ by se pro pročištění trochu čemeřice vzalo“ (PUCHMAJER: 4).

45) Vinařický v této věci argumentoval stejně, jako Šafařík v Počátcích. I on sylabotónismus vnímal jako německý a proto odmítal, nebot' není možno připustit, aby „řeč naše hodnější [...] pod Teutonkou se plazila“ (ŠAFAříK: 12); poněkud paradoxně byl tento prozodický systém přičinně spojován s úpadkem české poezie vůbec: „Co přízvučná prozodie germánská na český trůn vyzdvižená, všecko téměř prohráno“ (IBID.: 14).

46) Analogicky jsou pro Šafaříka „hudební Čechové, jejichžto výborný jazyk sám v sobě onu ouplně řeckou časomíru zřejmě nese“, proti čemuž stojí „nehudebné, v sobě nedůvodné přízvuku pravidlo“ (ŠAFAŘíK: 12). 
antických vzorů: „I což tedy zbývalo? Ode dřevních barbarů podaný sobě klinkavý rým na trůn poezie postavili, a slabiky spočítajíce, neměříce více, řekl bych, jako dítata ve stejnozvučném jejich výpadu se kochali“ (ŠAFAŘÍK: 11). V závěru právě citované pasáže zazněl charakteristický argument českých klasicistů. Také u Vinařického v souvislosti s versifikací čteme: „Mějte se ke skutkům uměle ozdobeným! / Shod’te vodítka dětí: mužskou nohou kráčejte!" (VINAŘICKÝ 1830: 56). Ke slovu tak zjevně přicházela starořímská a později v antických stopách i renesanční kategorie „virtus“, která ve svém širokém výměru neimplikovala pouze mužnost /zmužilost, nýbrž i dokonalost, výbornost, ctnost a ušlechtilost včetně náležité vzdělanosti (KÁBRT: 476), a stávala se tak emblémem klasicistního, osobnost harmonizujícího i zaštitujícího pojetí literatury, protikladného romantické jednostrannosti i výstřednosti citu.

\section{B) Pưvodní beletristická tvorba}

Analýza je limitována textologickými problémy. Soubor Vinařického textů máme $\mathrm{k}$ dispozici $\mathrm{v}$ podobě dvousvazkového posmrtného vydání z let 1871 a 1875, vydaného nákladem I. L. Kobera a uspořádaného básníkovým synovcem Václavem Otakarem Slavíkem, přičemž na druhém dílu se redaktorsky podílel František Zákrejs. V nestránkované předmluvě editor konstatoval: „Převzav [...] po vůli zvěčnělého strýce [...] další vydávání literárních jeho prací, dostal jsem se při samém počátku tohoto posvátného mi odkazu poněkud v nesnáz" (VINAĽICKÝ 1871: s.p.). Tou byla koexistence již dřive vydaných textů, rukopisů a opisů pořízených cizí rukou, takže „nelze tu rozhodnouti, jsou-li to naskrze skladby jeho vlastní, které zvěčnělý $\mathrm{k}$ tisku dával opisovati, a nepřimísila-li se snad tu neb tam nějaká práce cizá" (IBID.). Kromě autorské atribuce přnináší materiálový korpus i problém chronologie. Editor zřejmě respektoval projevené přání autorovo, s nímž na koncepci spisů ještě za jeho života spolupracoval, a předřadil ve spisech tvorbu pro mládež. $Z$ tvorby „pro věk dospělý“ (IBID.: 115) jsou jen některé básně datovány, a jelikož editor řazení souboru nekomentuje, není chronologie naprosto spolehlivá. Přesto je možno postihnout hlavní tendence proměn Vinařického poezie.

Nejstarší textová vrstva je bezpečně datována do počátku dvacátých let, tedy stále ještě do univerzitních časů Vinařického. ${ }^{47}$ Dominují tu přiležitostné a školské básně, představující dobově bezpříznakový počátek básnické dráhy. Poezie coby exercitium přitom přirozeně vycházela z klasicizujícího konceptu básnictví

47) Od roku 1818 studoval na pražské univerzitě filozofii, studijní rok 1820-1821 strávil ve Vídni. Poté absolvoval arcibiskupský seminář a na podzim 1825 byl vysvěcen na kněze. 


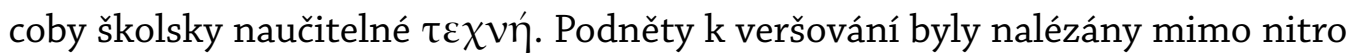
básníka ve vnějškových příležitostech, případně v látkách určovaných učitelem. Výuka postihovala všechny vrstvy básnického textu, od tématu přes motiviku, kompozici až po versifikaci. Exemplární je v tomto ohledu příležitostná báseň Řeč k výroční slavnosti druhého s Olympa sestoupení Zevsa na den památný jeho pozemského narození dvacátý čtvrtý, dne 6. prosince 1824 (VINAŘICKÝ 1871: 131-134). Text je členěn na části, opatřené mezititulky odkazujícími na obligatorní rétorické figury - exordium, captatio benvolentiae, invocatio, transpositio ad propositionem, confirmatio, argumentum $I-V$, conclusio, applicatio et practici. Osnova tedy vyplývá $z$ učební látky, ve školském cvičení koření i nezbytné latinské motto, odkazy na Démosthéna, Olymp, Phoeba, Dia či starořecké zeměpisné reálie.

Ve školské formaci pochopitelně kořenily i překlady antické klasiky. Pomineme-li pozdější obsáhlé, samostatně vydané překlady, vytvořil Vinařický ve dvacátých či třicátých letech i převody drobnější. Patří k nim texty z Horatia (SPISY: 163-174) a čtyři idyly z Biona (IBID.: 157-163), uvedené vysvětlením souvislostí z antické mytologie, včetně citátů $\mathrm{v}$ řečtině. Zejména odkazy Bionovi nebyly v poezii Vinařického současníků vzácností, jednotlivé verše se vyskytovaly i jako motta původní poezie (viz KOCIÁN: 44) a sehrávaly tak roli jakéhosi ideálního prototypu idylických či elegických básní. ${ }^{48}$ Antické vzory pravidelně pronikaly i do př́ležitostné poezie, která se svou povahou nalézá na rozhraní školských cvičení a ambiciózní autorské poezie. Jako pars pro toto uved’me v alkajských strofách psanou báseň z roku 1836 - Ku příchodu císařských královských Majestatností Františka a Karoliny do měst Pražských (IBID.: 178-179). Antikizující versifikace tu nabývala specifickou funkci: sugerovala dojem mimořádné důležitosti pojednávaného námětu, který se tak dostával mimo sféru běžné všednosti. Analogii z téhož roku nalezneme u Karola Kuzmányho. Ten sice $\mathrm{v}$ půli třicátých let experimentoval s kolísáním mezi antickými a romantickými veršovými a strofickými různotvary (viz KUZMÁNY: 653), ale přiležitostné básni Pláč nad smrtí Karla Hynka Máchy (IBID.: 46) dodal na patetické vznešenosti užitím jinak zcela přehlíženého elegického disticha.

Právě elegie byla typem poezie vhodným pro interference klasicismu a romantiky. Versifikační aparát i obraznost nabízely školská výuka a antická tradice, subjektivně zaujatý a citově vznícený prvek mohl být nesen osobní situací

48) Analogicky mohli fungovat i jiní autoři, tak de la Motte Fouquè, podle nějž Jan Herzog složil cyklus idyl a ke svému vzoru se přímo odvolal v podtitulu (viz HERZOG: 82-108). 
autora, zvláště pokud se jednalo o velmi frekventovanou elegii náhrobní. ${ }^{49}$ Část z př́islušných básní replikuje antické prototypy a je překladem nebo jen velmi volnou adaptací. Vinařický kupříkladu přeložil Žalozpěv nad Adónem (SPISY: 157-161), přičemž analogií byla mimo jiné i Palackého elegie s incipitem Kvěj, zpěve můj, po Adonisu: Krásný zesnul Adonis! (PALACKÝ: 77) a starší obdobou Rožnayova přízvučná elegická disticha U hrobu Anakreonova (ROŽNAY: 86). Nejde tu o úplnost katalogu případů, ale o podstatu věci: zármutek nad smrtí nemůže být spojován s autorovým niterným prožíváním. Jinak tomu mohlo být v případě jiné Vinařického elegie Žalozpěv u hrobu přítele (SPISY: 119-120). Ta koření v osobním prožitku, datovaném letopočtem 1822, tedy do devatenáctého roku autorova života. Tvar devatenácti elegických distich, stejně jako obraznost jsou i zde neseny tradicí. Také citově vypjatá reflexe „Ted’ slza má skrápí rov tvůj“ či stejně emocionální zvolání „což? - neuzřím tebe víc?“ (IBID.: 120) mají jistě analogii v antických, ale i barokních vzorech. V okamžiku bezprostředního prožitku ztráty blízké osoby ale jistě text mohl souznít s hnutími nitra mladého autora. Právě v desátých a dvacátých letech, tedy před manifestací máchovské varianty subjektivity, ostatně básnící ani neměli jiný dostupný způsob, jak příslušné emoce literárně vyjádřit. Blízko ze současníků v tomto ohledu byli Vinařickému např́klad Jan Herzog v básni City při pohřbu přítele mého Jana Šnajdra (HERZOG: 41-43) či Na hrobce mé milenky (IBID.: 49-50), František Trnka v elegii Na smrt mé drahé matky (TRNKA: 6) či konečně Palacký v alkajských strofách U hrobu př́tele (PALACKÝ: 43-45).

Osobní citovou účast autora sice nemůžeme ani $\mathrm{v}$ jednom $\mathrm{z}$ právě uvedených př́kladů s jistotou doložit, i když ji můžeme s velkou mírou pravděpodobnosti předpokládat. Přesto máme doklad proměny žánrového povědomí elegie od klasické nezaujatosti k romantické angažovanosti. V první verzi své Slovesnosti (1820) Josef Jungman charakterizoval elegii taxonomicky, vymezením jejího místa v žánrovém a estetickém systému. Podle příslušné pasáže „Elegie jméno pošlo ze slova $\varepsilon \lambda \varepsilon \varepsilon \omega$, t. polituji, a znamená žalostnou, truchlou, plačnou píseň, žalozpěv; jest pak nižší lyrická báseň tiché a smísené city s převahou libosti nad nelibostí vystavujíci“" (JUNGMANN 1820: XL). V dalších řádcích se stanovuje poměr elegie k písni a ódě. Ve vydání Slovesnosti z roku 1845 začíná pasáž identicky, ovšem jen po slovo „žalozpěv“. Pak je elegie vymezena emocionálně,

49) Pro období 1795-1825 registruje Thesaurus českých meter 75 elegií, z toho 39 náhrobních, přičemž výskyt nápadně kulminuje ve dvacátých letech. Thesaurus českých meter 1795-1825, dostupný na http://isis.ucl.cas.cz., přístup [4. 2. 2016]. Zatímco předchozím maximem byly v roce 18134 elegie, pro rok 1822 je registrováno 6 a pro rok 1825 12 elegií. 
jako výraz „rozníceného nadšení“ (JUNGMANN 1845: 110), kdy se „cit kloní k truchlivosti, k sladkému neb trápícímu toužení“ (IBID.). Specifičnost žánru již není určována poměrem k žánrům jiným, nýbrž citovým rázem: „truchlivost [...] jest ráz elegie“ (IBID.). Nově se také klade důraz na tvůrčí subjekt: „V elegii především vystupuje osobnost básníkova“, přičemž „cit tišším proudem a jako rád se vylévá“ (IBID.). Jungmann sice brojil proti subjektivně přepjaté variantě elegie: „Varovati se náleží nemužného žalostnění a přetvařovaného rozčileni“" (IBID.). Přesto rozlišil mezi elegií a „citem elegickým“, který dokonce může expandovat i do jiných žánrů, tak do ódy či tragédie (IBID.).

Cit autora jako základ básně bezpochyby spočívá v základu Vinařického textu List Josefu Jungmannovi ml. (SPISY: 135-136). Svého druhu př́ležitostná báseň je datována a lokalizována do Teplic v červenci 1825. Podnětem byl lázeňský koncert nejmenovaného českého houslisty. Textem se mihne motiv vlastenecké hrdosti. ${ }^{50}$ Klíčový je ale motiv osamělosti jinocha uprostřed společnosti: „Lidným bloudě nyní městem, mním býti více na poušti; / smutně hledím, co labut’, po vodách ana vesluje pustých“ (IBID.: 136). Z pocitu sklíčenosti nenalézá lyrický subjekt východisko: „Ach! Utěchu všady bol stíhá!“ (IBID.: 135). Scéna tedy má romantické parametry, jaké najdeme například ve vstupních partiích Máchovy Marinky. Romanticky je pojata i funkce hudby, která jediná - opět jako $\mathrm{v}$ právě zmíněné Máchově próze - může vnímavého mladíka přenést $\mathrm{z}$ reality do světa citově vzníceného estetického prožitku a zároveň jej spojit s podobně cítícími druhy. ${ }^{51}$ Lyrický subjekt hudbou okřeje: „houslí jeho prozvukováním / nadzemským nadšen jsa duchem“, houslista „city v útrobu vléval nadzemské“, „líbezná hra jeho v rajské mne vkouzlila říše“ (IBID.: 135-136). Versifikace básně je vzorně klasicistická, tvoří ji časoměrná elegická disticha. Tvárné podloží ale bylo překryto subjektivně romantickou sémantikou, v roce vzniku básně (1825) velmi př́íznakovou.

Vinařický se tedy jako básník do své třicítky dostával do silového pole různých literárních diskurzů. Dobrou ilustrací může být dvojice básní z konce dvacátých a počátku třicátých let. Rokem 1830 je datována Plavba v Podolí (SPISY: 141-142). Korespondence tu doložila reálný podnět vzniku textu: „Vstoupili jsme do lodě, a již míjely břehy, palouky a skály, v pravo i v levo vše ubíhá vzad. Aj, tam Čechů někdy slunce. Na smíchovském břehu přistanuv ohlížel jsem se ještě jednou na Vyšehrad“ (KORRESPONDENCE I: 179). Podnět byl ale do ko-

50) Houslistovi je doručen pochvalný dopis pruského krále, což lyrický subjekt glosuje: „Jsout zdární synové skvostná své oslava vlasti!“ (SPISY: 136)

51) Ideálem lyrického subjektu je „se soucitlivým se procházeti družcem“ (SPISY: 135). 
nečného tvaru přetaven hned několikerým filtrem literární tradice. Antickým prototypem „lodní ódy“ je pro danou dobu nepochybně druhé číslo z první knihy Horatiova cyklu Carmina, známé všem dobovým vzdělancům a rozššřené i u nás. ${ }^{52}$ Klasicistní podloží jeví i vzorně časoměrná verisfikace elegických distich Vinařického textu. Obsah je však vlastenecky romantický s jasnými aluzemi na Rukopis Královédvorský. Prostorovou dominantou se stává mytický Vyšehrad, $\mathrm{z}$ vody pod ním se vynořuje fantaskní postava vodní víly, želící že „nepěje více Lumír“, kterému kdysi „kolébala člun“ (SPISY: 142). Motiv graduje citovou reakcí lyrického subjektu: „Rozbolelo mne tu srdce želem; slza smáčela líce / rozželen opakuji: Nepěje více Lumír!“ (IBID.). Vyústěním trojdílné expozice a současně vyvrcholením celé básně je pak apostrofa Čelakovského jako nového Lumíra (IBID.). Intertextualita tedy přicházela ke slovu hned několikerým způsobem, přičemž romantické prvky na klasicistickém podloží dominovaly.

Druhá ze zmíněných básní je z roku 1828 a již titulem sugeruje další modifikaci „lodní ódy“: Fantasie při plavbě ode Ždákova k Vorlíku dne 27. července 1828 (SPISY: 136-140). Titul strhuje pozornost slovem „fantazie“. Povýtce romantický výraz jistě měl kořeny v německé literatuře, především v Schillerových básních Pohřební fantazie a Fantazie Lauře, známých u nás jistě v originálu a přeložených do češtiny roku 1841 Janem Evangelistou Purkyněm (PURKYNĚ: 54-60). Podnětem ke vzniku básně byl Vinařickému zážitek romantického putování, vzpomínaný v korespondenci: „Ubíraje se k Rožmitálu, stále ještě jsem v duchu bloudil s Vámi po luhách utěšeného Vorlíka. Rozmanité obrazy stupovaly před duši mou, a pocity bezejmenné pohybovaly srdcem rozčileným. Nejvíce mne ale dojímala plavba po Vltavě: ještě jednou jsem do lodě s Vámi stoupil, a mysl má zabrala se do fantasí při plavbě od Žd’ákova k Vorlíku. Divoká to fantasí! Který rozumný člověk s lesy, skalami, vodami atd. rozmlouvati bude? - Pán Bůh mne uzdrav! (KORRESPONDENCE I: 83-84). Okouzlení romantikovo a rozpaky klasicistovy tu máme přímo před očima.

Východiskem děje se stalo toponymum Ždákov, romanticky etymologizované ve smyslu ždáti, tedy čekat, toužit, které asociovalo tragický milostný příběh, situovaný do romantické dávnověkosti. Poměrně jednoduchá konstelace, založená na milostném trojúhelníku, generuje stejně jednoduchou zápletku. Důraz je zato položen na zpo̊sob vypravování: básník apostrofuje lesy a skály,

52) Kromě originálních znění a německých překladů této ódy existovaly i české verze. První pořídil roku 1814 Václav Svoboda s titulem Na lodi, na níž se Virgil do Athén plavil (PUCHMAJER 1814: 61-62), další Vinařickému dostupný a snad i známý překlad představovalo přetlumočení J. Hollého z roku 1824 (HOLLÝ: 76-77). Vlastní Vinařického překlad obsahují Spisy na s. 172-173. 
ty vyprávějí příběh únosu milované dívky. V momentu dějové krize antagonista zabíjí protivníky, což je vyjádřeno stylem hrdinské epiky homérské i ossianovské ražby: „vztekem rozjitřený / prudce po nich [prchajících milencích - DaT] / těžkým mece mlatem. / Rozrazí se lod’ka, / utonou ve vlnách“ (SPISY: 139). Romantickou povahu má následující response přírody: „Zaječely vody, / Zašuměly bory / žalostivým steskem / i [...] tvrdé skály / slze vyronily, / slyšíce na břehu / želebohů lkání“ (IBID.). Zřetelný podnět vlastenecké romantiky se ale promítl i do tvaru básně, což jinak nebylo u Vinařického obvyklé. Základem se na rozdíl od klasicistní tektoniky stala nepravidelnost. Oddíly jen volně dávající tušit obrys strofiky se střídají s pasážemi zcela astrofickými. Podstatnou roli přejímá rým, který je ale také velmi nepravidelný, a to ještě kolísá od rýmu kanonického (hory/bory), k absolutnímu (stíny/stíny) a převažující asonanci (skály/hlavy). Řada veršů se do rytmické struktury vůbec nezapojuje. ${ }^{53}$ Zcela nezvyklý způsob versifikace sugeruje dojem starobylosti, a to radikálně jiné, než je vzornost antické klasiky. Báseň tak je nejvýraznějším projevem Vinařického experimentu $\mathrm{s}$ romantickým typem poezie. A v dopise jednoho z přátel nalezneme i svědectví o ryze romantické recepci této básně: „Báseň Vaši posouditi umělecky není má věc, cítím ji hluboko a tak i pan vrchní, jemuž jsem ji četl. [...] Pana vrchního při čtení [...] slze polily“ (KORRESPONDENCE I: 84; 1828).

Mnohem rozsáhlejší je korpus děl, v nichž se Vinařický proti romantismu vymezoval. Polemika s romantikou se mu stala návratným tématem a její důležitost dokládá i soustřed’ování příslušných textů do komponovaných celků. Úplnou a přesnou chronologii nejsme s to stanovit, přesto je jasné, že zatímco interference s romantikou spadají do raných fází tvorby, podstatnou část protiromantických básní lze situovat do třicátých a do první poloviny čtyřicátých let. Prvním soustředěným projevem polemiky je patrně drobný cyklus nazvaný Lyra (SPISY: 153-157). ${ }^{54}$ Symbolické slovo titulu odkazuje k antické tradici, výslovně je zmiňována „lyra lesbická“ a pouze antikizující básník se zdá být „k vyššímu posvěcený letu“ (IBID.: 154). Pohrdavě se mluví o „rýmu prázdném“

53) Z 35 veršů prvních tř́i strof se 17 veršů vůbec nezapojuje do rýmové struktury (49 \%), 9 se navzájem pojí asonancí (25\%), absolutní rým váže 7 veršů (20\%) a štěpný rým nalezneme v pouhých 5 případech (14 \%). Přitom ještě mezi slovy potencionálně spojenými některým typem rýmu mohou ležet i 4 verše, takže vznikla velmi nepravidelná struktura plná tvárného i sémantického napětí.

54) Spolehneme-li se na chronologický princip řazení v jednotlivých oddílech sebraných spisů, v tomto případě jejich části č. II, nazvané Pro věk dospělý, spadal by vznik cyklu patrně mezi roky 1830-1834. Odpovídalo by tomu i předřazení textů souvisejících se setkáním s Václavem Stachem, které se odehrálo ve Vídni roku 1829 a bylo Vinařickému podnětem $\mathrm{k}$ obnovenému a ještě intenzivnějšímu zájmu o klasicistní typ literatury (viz SPISY: 149-153; na s. 143-148 je nejprve přetištěna Vinařickým nepatrně upravená Stachova báseň České veršovství, na následujících stránkách pak Vinařickým složený Ohlas lyry starého veršovce; původně byly texty publikovány v Časopise českého musea r. 1829 a 1830, což také projasňuje chronologii). 
(IBID.), zatímco „švarná i dle míry řecké / tancuje Češka“ (IBID.: 155). ${ }^{55}$ Nejde ovšem jen o nápodobu antické versifikace, řečeno básníkovými slovy o snahu „zpívat nápěvy, / jimiž si, Kalliope, ondy mě učila, / ač zdálo se, že českých / se rtů nikdy nepoplynou“ (IBID.). V centru polemiky stojí subjektivně romantický koncept básníka, jeho „rozervaná duše, v životě / která v šílenství boj vede stálý [...] nevěří, nedoufá,/ sebe boží [zbožňuje - DaT], napohled však zoufá“ (IBID.: 148). V jádru romantické subjektivity spočívá „nemoc [...] pýchy“, jejímiž projevy jsou „sebeklamné smíchy“ či „licoměrné stonání a křeče“ (IBID.). Identicky vyznívá i pozdější cyklus Plané růže, věnovaný Čelakovskému, dokončený roku 1844 (IBID.: 262-264) a vyzývající literáta „slepě citům se neoddávej, básníku mladistvý; / básněm bez rozumu světla paprsky chybí“ (IBID.: 263). Jinde Vinařický varuje: „Moudře city hlídej, jako hlídáš plápoly ohně; / nezkrocená vášeň zhoubami ohně hrozí" (IBID.: 264).

Báseň Sokovi na dorozuměnou (SPISY: 265-266) ukazuje, že se přitom jednalo o součást explicitní polemiky. $V$ duchu výše citovaných veršů, ale tentokrát v přímém dialogu s oponentem je odsuzována romantická subjektivita: „Ty vždy nyješ a lkáš a želem své srdce rozrýváš, / i křeče sobě lžeš: proč?" (IBID.: 265). Kritika je ale důsažnější a obrací se i proti subjektivně romantické negativnosti: „sám sebe věčně moříš, tvůj se tělem hyne duch. / Dráhu hledáš ztracenou [...] / Všecko vrháš do propasti, zapíráš naději spásnou“ (IBID.). Odsouzen je i byronovský či pro naše poměry máchovský obraz jedince: „Člověk mi člověkem, neměním ho na anděla-d’ábla“" (IBID.). Vyústění básně ještě jednou ve výmluvných metaforách a aluzích staví vlasteneckou literaturu nad tvorbu subjektivně romantickou: „nad noční já světla stavím denní toto slunce [...] / Dej mi ruku, krajane, světýlkem svést se nedávej; / tot poutníka vodí do tmy čirých kalužin. / Netkni se víc těch zádumčivých strun harfy severní: / tím co Lumír varitem břinkni a vlast’ oslavuj“ (IBID.). Pasáž Vinařický zjevně považoval za klíčovou. Její přepracovanou a adresněji proti Máchově poezii zacílenou verzi totiž roku 1841 zařadil do satirických Sněmů zvírat. ${ }^{56} \mathrm{~V}$ jiných verších Vinařický satirizoval

55) Protiromantická polemika probleskla i do humorné deklamovánky Taroky, kámen mudrců (SPISY: 180-194). Kromě narážek shakespearovské postavy a Scottovy romány, odkazů na „krásy romantické / i památky praklassické“ (IBID.: 182) tu je i ironický odsudek rýmované poezie: „věru, neskládal jsem tolik pěkných rýmů / jindy za týden, co nyní za hodinu“ (IBID.: 192). Modelovým čtenářem Vinařického deklamovánky tedy musel být vzdělanec; na druhou stranu je užití literárních aluzí dokladem obecnějšího rozšiření protiromantické polemiky v širších kulturních kruzích.

56) „Sám sobě rány děláš napořád sebe bodaje dýkou. / Rovně tak Indický marně mučí se Fakír. / Nikde nemáš stání; sám útěše srdce ubíháš; / odpor nejvyšší lidstva idéi kladeš. / Vlasti domov neznáš; Tebe vábí harfa severní; / za zvuk ten jediný vše vnady vlasti by dals'. / Dráhu hledáš ztracenou; ta mizí Ti na západě temném. / Tě klame luna bledá; zoufaje věčně toneš. / Dej mi ruku, krajane; světýlky svést se nedávej; / tat poutníka vodí do tmy a bezdna 
„atlantský rukopis“, psaný „frapantními [...] nerýmy“ [...] často bez pout metriky“, jehož zdrojem je „svobodný věku Genius“ (IBID.: VIII). Některými detaily Vinařického polemiky s romantikou, jak je najdeme ve Sněmech zvírat, jsme se zabývali jinde (TUREČEK 2012: 102-103). Zmiňme proto jen zjevnou parodii známé Vilémovy meditace pasáže z druhého zpěvu Máje; Vinařický tu parafrázoval nejen myšlenky, ale i přerývaný, $\mathrm{z}$ hlediska klasicistního ideálu naprosto skandální styl versifikace: „Kde nic - není - / tam nic - není.“ - / [...] „Hlava má - je prázdný strop, / břicho moje - smyslů hrob, / trochu větru - jest můj duch, / mozek pára - srdce puch; / ze mne - jako ze všeho - / nezbude - nic ničeho; / všecko vejde - v zapomenutí; / scepeně i já - / pominu i já!“ (IBID.: 37-38).

Stejně byly zesměšněny i typické hřbitovní motivy a látky: „V koutě trhá sebou Hyéna; / romantikou, / politikou / rozervaná, rozkyselená, / kypí pomstou proti lidu; / ani v noci nemá klidu; / mrtvých z hrobu vyhrabává" (IBID.: 61). ${ }^{57}$

Zatímco Sněmy zvírat byly neseny ironicko-polemickým tónem, ve sbírce Varyto a lyra (1843) Vinařický uskutečnil pozitivní představu svého výměru poezie. Záměr ani význam se tedy nevyčerpávají jen pokusem o jazykové a prozodické novotaření, na něž bývá kniha zpravidla redukována. Vstupní báseň Obrana zvuků českých (VINAŘICKÝ 1843: III-IV) zjevně navazuje na obrozenskou tradici apologií národního jazyka, ale též na Kollárovo vymezení básnických kvalit češtiny. ${ }^{58}$ Veršovým půdorysem je ale elegické distichon, a tak se vlastenecká ideologie prolíná s klasicistním uměleckým ideálem. Z našeho úhlu pohledu se jeví jako klíčová báseň Varito (IBID.: 1-2), tematizující lyru coby symbol antického typu poezie a lumírovské varito jako příznak vlastenecké romantiky. Analogicky dvojčlenná je i struktura básně. Lyrický subjekt nejprve upomíná Ariona, Múzu a proklamuje: „Ó by mě učila ta bohyně / po umělé Helady míře / dušejímavé té lyře“ (IBID.: 1). Protože ale „Múzy / nebytují více / na zemi

bahen. / Zbortěna harfa je Tvá; ztrhaných již netkni se strun těch: / tím, co Lumír, varytem břinkni a vlast’ oslavuj!“ (VINAŘICKÝ 1863a: VI)

57) Svůj koncept smrti Vinařický vyslovil v cyklu 5 epigramů se společným titulem Šepty z hrobů (SPISY: 255-257). Smrt je tu v protikladu k máchovskému romantismu nahlížena z křestansky potěšujícího úhlu a cyklus je výmluvně završen básní s titulkem Vzkříšení.

58) „Češka samé jasné samohlásky zná, jako Vlaška; / Temným ü neb ö usta si nestahuje. / [...] I měkké spoluhlásky tvoří, jíchž Němkyně nezná; / Ty v řeči poskytují proměnu rozmanitou. / Než jaková zvuček a samohlásek v češtině vládne / Míra; tu, sousede, viz důkazy předložené. / Zde vždy jenom jediná se střídá zvučka po hláskách; / Viz to a nemluv nám, že tvrda řeč je naše. / Chcešli zahanbiti nás, poukaž nám písně podobné / V němčině své: a hned palmu podáme my ji“ (VINAŘICKÝ 1843: III-IV). Argumentace je tu shodná se znělkou 504 Kollárovy Slávy dcery: „Než řeč naše nejen nemá hmotů / Jako bl, kl, sl, ml huhnavé, / Aneb dr, pr, tr, vr štěkavé / Od Germanů půjčené a Gothů; / Nýberž chrání se i od škřehotů, / Zvléká pomalu ř břískavé, / Slala iikání kvičlavé / S eekáním k mezem Hottentotů: / Milostné a, pak o převelebné / Vracejí se zpátkem z vyhnanství, / Bejk, šejd, hejl - tu hnusné, nepotřebné; / Každá tě̌̌ká, přebroušená, divá / Hláska ztratila tu měštanství, / Hudbu má řeč naše zlatoznivá“ (KOLLÁR 1832: 266). 
kamenité“ (IBID.: 2), obrací se tok textu k tradici utvářené Rukopisy: „Tamo na lípě věkovité / visí Lumírovo varito. / To, se suku vypjato, / rokotavými vzdechy / samo vybudí Čechy“ (IBID.). Obsahově báseň jistě nepřinášela nic podstatně nového. ${ }^{59}$ Zato tvar je poměrně složitým a originálním experimentem, neseným sice sylabotónickým spádem verše, ale bránícím se jakékoliv mechaničnosti opakování a akcentujícím stále se měnící různotvárnost. ${ }^{60}$

Napětí zavedeného obsahu a inovativního tvaru se nese celou sbírkou. Předzpěvu Kollárovy Slávy dcery odpovídají motivy skvělé minulosti dávných Čechů a ztroskotání jejich společenství cizími nájezdníky. ${ }^{61}$ Také v básni Na Zasáví (IBID.: 27-29) se kollárovské motivy slovanské poroby transponují do jihoslovanského prostoru, přičemž je zachována řada myšlenkových figur i jednotlivých výrazů, které byly pro dobového čtenáře zřetelným signálem spřízněnosti $\mathrm{s}$ Kollárovým Předzpěvem. ${ }^{62}$ Jiné texty jsou nepokrytě inspirovány Rukopisy (tak b. Milina, IBID.: 45-47). ${ }^{63}$ Řada plenérových písní, apostrofujících přiro-

59) Jako pars pro toto uved’me jen sbírku Jana Kociána z roku 1824, jejiž úvodní báseň, následující po dvou latině psaných sapfických strofách s funkcí motta, je též vyjádřením touhy po poesii „rukopisně staročeského“ typu a počíná výmluvným incipitem „Kýž mi dáno zpívat Lumírovým duchem“ (KOCIÁN: 3-5) Svazek nadto obsahuje variaci květomluvné rokokové poezie s rukopisnými motivy, nazvanou též instruktivně Lumírův vínek (IBID.: 19-23).

60) Ve čtyřiadvaceti verších textu kolísá rozměr mezi šesti a dvanácti slabikami, převážně trochejský spád je rozrušován jambickými i daktylskými prvky, napětí mezi ideálním metrem a realizací je vnášeno hojnými dipodiemi. Jako nejsložitěǰś se jeví rýmová struktura, komponovaná na napětí obkročného a sdruženého půdorysu s vloženými verši bez rýmové shody a zároveň rozpjatá mezi asonancí, polorýmem a rýmem kanonickým (k typologii rýmu viz IBRAHIM - KOLÁR - ŘÍHA: 66). Vinařický tedy užil rýmu, který jako neantický a „nízkopoetický“ odmítal u romantiků, ale učinil tak s rafinovaností, jaká neměla v české produkci jeho doby analogii.

61) „U Dunaje i na Sále, / Za Labem i dále / U moře obývalo / Několiko národů; / Milé pouto jazyka i původu / Se Čechy je vázalo. / Mejtívali lesiny, / Bory, dubiny. / Ve vyduté báni / Kopávali rudu; / Ze železa, ze mědi / Kuli kosy a k orání / Nářadí. / Neradi / Do divoké seče / Hotovili meče: / Raději / Pokojnou orali půdu. / Na dole i hoře / Budovali chyše; / Veselými / Jeky / Za koráby jejich a lodími / Pěnilo se moře, / Pěnily se řeky. / Žili tíše; / Na luhu, i na poli, / Na horách i v údolí / Pĕli vesele; / I žele / Pěním ukojili. - / Časové se vyměnili. / Ze severu ode moře / Na naše rodáky / Řítilo se hoře; / Železem i ocelí / Odění cizáci, / Porénáci, Zalabáci, / Násilím i položenou léčí / Napadali na naše jonáky. / Po tisíceré na poli seči / Lidé tiší unaveni, / Do poroby uvedeni. / Na poli a luhu zanikalo / Veselé pění / Mezi horami se ozývalo / Úpění. / Ze paměti lidu mizí / Věci minuté. / Nyní, jako cizí, / Rození dědiny této synové / Nevědí, co byli dědové, / Nemajíce ani péči, / Aby rozuměli dědů řeči / Zapomenuté. / Dědů jazyk uchovaly / Vody jen a hory, a my šumy, / Sypané mohyly, valy" (VINAǨICKÝ 1843: 13-16).

62) „Sáva teče do Dunaje, / A Dunaj do moře: / Duše má za ně zalétá / A ji žere hoře. / Oko zírá pole, háje, / Roviny a výše: / Aj tu leží Dušanova / Zahynulá říše! / Široké Kosovo pole / Žele moje budí, / A mou duši žalovati / A upěti pudí. / A co moje porosené / Vủkol oko vidí? / Pány divochy, a tiché / Ve porobě lidi! / Mohamedovi tu zư̌í / Dosaváde kati: / A věku vybuzenému / Duchu meze hatí. / Loupeživí tu padouši / Panují a káží, / Panen a rodičů city / Zavile uráží. / Běda, běda, čí to vina, / Že Zasáví touží, / Lítí že je celé věky / Biřicové souží! / Mouřenínů lituješ, ó / Věku lidomilý! / Dokavad upěti budou / Tady lidé bílí? / Nevěří na soudy Boží / Lidé nevěřííi: / Nenadále nebe metá / Šípy kárající. / Ač i noví Janičaři / Jinochy ti dáví, / Ubohý nezoufej lide, / Lide na Zasáví! / Co věk ulíčený říká, / Že nyní nemůže, / Nečekaná, netušená / Doba ti pomůže! (VINAŘICKÝ 1843: 27-29).

63) „Letěla do pole, / Letěla do lesa / Holubice: / Ničeho na poli, / Ničeho po lese / Nezobala. / Holuba volala, / A ho neviděci / Žalovala, / A lidi vinila, / Že ho poranili / A zabili. / I děva Milina / Utěchy neměla / Doma sama. / Po poli běhala, / Po lese těkala / Semo tamo. / Nedochodila si / Pokoje na poli / Ni po lese: / U sadu, u chyše / Nyje, hořekuje / A běduje. / Co je ti Milino, / Že tobě s oka se / Rosa lije? / Co tě zabolelo, / A co zakalilo / Tobě duši? / Vy-li neviděli 
du a venkovský život včetně hudby a tance, zase upomíná na Ohlas písní českých. Proto ale ještě nelze souhlasit s výše citovaným náhledem, podle nějž je neskrývaná, ba akcentovaná návaznost na literární tradici projevem bezcenné odvozenosti. ${ }^{64}$ Ani jeden z textů, na něž Vianřického verše explicite navazují, přece v roce 1843 nebyl petrifikovaným literárním faktem; Kollárovo dílo dokonce ještě ani nedoznalo své definitivní podoby. Pretexty Varyta a lyry se naopak nacházely na vrcholu své prvotní recepční vlny ${ }^{65}$ Vinařický s nimi navíc nezacházel pasivně, ale vnášel do svých textů modifikace, které mohl dobový čtenář vnímat jako obohacující hru. Výše jsme zmínili užití kollárovské optiky Předzpěvu na speciálně české poměry. Jiným příkladem budiž báseň Na Pováží (IBID.: 23-24), apostrofující Slovensko s národními bardy Hollým a Kollárem. ${ }^{66}$ Báseň U potoka (IBID.: 32-33) ${ }^{67}$ je ze se polemikou s jinošskou vášní, tedy se základem subjektivního romantismu. Balada Dítě umírající (IBID.: 75-78) pak představuje psychologizující variaci látky známé z Goethova Erlköniga a nevztahuje se ke vzorům z literární tradice, nýbrž naopak nápadně předjímá Nerudovu Baladu dětskou. Sbírka tedy představovala uzlový bod hned několika tendencí.

Modifikační charakter ale nespočíval jen na rovině látek a motivů. Tvárný experiment, neprávem odsuzovaný jako „titěrný formalismus“ (viz pozn. 57) přinášel důmyslně prokomponované, a přitom působivé verše. Citujme jen ad illustrandum závěrečné verše naposledy zmíněné balady: „Ponocuje chudá žena; / Ku dítěti nachýlena / U lože potichu sedí, / A co asi tuší / Ve bolavé duši, / Její city vědí. / Máti! milá máti! / Nebudu se báti. / Viz, ej, pacholíka tady; / Na peruti letí, / Kyne mi a ukazuje / Utěšené sady / A zelené háje, / Jako ráje. / Duše moje veselí se. / Pacholíček utiší se. / Máti se dítěti / Do náručí vine; -/ Rosa z oka jí se line - / Líbá, rosí bílé čelo, / Líbá fialové líce: / Ledovité ale tělo /

/ Do pole Kochana / Reka jeti? / Sasi ho ve boji / Zuřivě ranili / A zabili. / Po choti Kochanu / Duše moje tady / Hořekuje; / Po reku Kochanu / Tato mi s oka se / Rosa lije" (VINAŘICKÝ 1843: 45-47).

64) „Vinařický zvrátil ve Varytu a lyře (1843) preromantické úsilí o vytvoření poetické formy v absurdní a titěrný formalismus. Jeho poezie, $v$ níž obnovoval stará preromantická témata, především přírodní idylismus, stojí pod úrovní sentimentální lyriky" (ŠTĚPÁNEK: 354).

65) Termín jsme zavedli v knize České literární romantično, kde jsme jej i metodologicky ukotvili a explikovali právě na př́padu Slávy dcery (viz TUREČEK: 106-111).

66) „Ráda a nelíná / Za rumy Děvína / Ku Váhu putuje / Duše má. / Operutěná / Zaletuje / Na vysokou Babíhůru, / Na Roháč a na Magůru: / Netušený jí se jeví ráj: / Tater aj tu holé výše, / Jezera a vodopády, / Úbočí, salaše, doly, / Živé dědiny, a rolí / Se zelenavými sady; Hollého tu zalíbený háj, / Na Dunaji Kollárova chyše! / Žíte věky, tiší vy geniové, / Váhu podaření synové, / Lyrou vyluzujte / Dušejímající tóny; / Ku životu vybuzujte / Duší miliony! (VINAŘICKÝ 1843: 23-24).

67) „Po dolině / Potok utíká. / Toky jeho / Ani zima líná / Ledy neupíná. / Ze dutého / Země lůna vyniká; / Hojně se řine, / Jaře se vine, / Toky ručí / Lívá po lučině. / O kameny / Hází pěny. / Na nebi-li boư̌e hučí, / Kalí se, kypí, duje; / Běhutý, / Nadutý / Vody šiří, / Ječí, virúí, / Luhy a palouky ruje, / Tarasy, násepy boří, / Lidu se nepokoří. / Boư̌e mine, / Minou, / Hynou / Pěny, šumy, jeky. / Potok utišený / Padá do řeky. / Potoku-li se nepodobá / Vášeň i jinochová?" (VINAŘICKÝ 1843: 32-33). 
Líbání necítí více“ (IBID.: 77-78). Efekt tu nespočívá jen v notoricky uváděné hláskové instrumentaci, vylučující souhláskové skupiny. Tato vrstva verše na sebe naopak nestrhává pozornost a vůbec už nevytváří dojem titěrnosti. Metrum je neseno napětím mezi ženskými a mužskými trocheji o různém rozměru (kolísá mezi čtyřmi a osmi slabikami), rýmová struktura stř́idá sdružené a obkročné pasáže s některými solitérními klauzulemi. Celek pak vytváří dojem nestrojené poezie, jejíž důmyslně vystavěný tvar nebrání spontánnímu vnímání sémantického gesta.

Mezi tradicí a inovací se ostatně pohyboval i Vinařického převod prvního a šestého zpěvu z eposu Jána Hollého Svatopluk (SPISY: 197-234). Podstatný byl už výběr přeložených partií. Vstupní pasáž prvního zpěvu, Svatopluk vězeň, je variací motivu truchlivé meditace nevinně žalářovaného hrdiny, velmi oblíbeného nejen v české, ale i evropské romantické literatuře. ${ }^{68}$ Zřetelným identifikátorem se subjektivně romantickou obrazností je „těžký nářek truchlivého“, který se „utrápen“ ptá: „zdaž v úzkosti jenom a samých želech uplyne věk můj?“ (IBID.: 197). Vězně skličuje „neustálá a slepá [..] mrákota“, ze které neprohlédne „ani slunka, anižto plné spanilosti měsíce“ (IBID.: 198). Typické je i doptávání po důvodu trestu: „A proč ale, pro jakou zde mě příčinu [...] vězníte?“; „Což jsem dál zavinil?" (IBID.). Zcela v duchu výše citovaných Vinařického výtek subjektivním romantikům ale text nenechá vězně pohltit duševní krizi. Nejprve zazní gnómická doxa, představující v klasicistním duchu utrpení jako nabádavý prototyp životní situace: „Učte se, kdo z lidské moudrý je bolesti, je moudrý, / učte se ze mne nyní, čerstvý tady berte si příklad“ (IBID.: 197). Východiskem se pak stává křestanská naděje v Boží milosrdenství, vyslovená vězňovou modlitbou (IBID.: 199-200).

Druhý přeložený oddíl, Kolébka národů slovanských, zase zpracovává romantiky velmi ceněný etiologický mýtus. ${ }^{69}$ Koncept obsahuje řadu dobově příznakových prvků, počínaje představou indického prapůvodu: „India nejprvnější našehot je pronárodu matka / a pravý původ“ (IBID.: 218). V kollárovském duchu je vymezen i slovanský areál, počínající „mezi Tisou a hrubým Dunajem“ (IBID.: 229), ale sahající „od Adrie k Baltu“, hraničící „na břehách Belgických“,

68) Pro české prostředí pochopitelně máme na mysli Máchův Máj (1836), ale motiv ve 30. a 40. letech nalezneme v řadě dalších básní (pro základní informaci viz databázi Česká elektronická knihovna). Z evropské literatury zmiňme alespoň Byronovu poemu The Prisoner of Chillon (1816) a Hugovu novelu Le dernier jour d'un condamné (1829). Př́slušnou scénu ale nalezneme v řadě jiných dobově populárních děl, tak v Bulwer-Lyttonově románu The Last Days of Pompeii (1834), jehož verzi pro mládež převedl z francouzského znění pod titulem Poslední dnové města Pompejí. Př́běh ze života starých Římanů Václav Klement Püner (1847; tam viz s. 159-160). Speciální motiv uvězněného krále obsahuje mj. Grillparzerova hra Der Traum ein Leben.

69) Různotvarům dobového zpracování látky o příchodu Čechů jsme se i s odkazy na literaturu předmětu věnovali jinde (viz TUREČEK: 174-217). 
„na Rejně“ a expandující „do samé ano Anglie“ (IBID.: 233). V duchu kollárovských stereotypů pradávní Slované též „se štěpením stromoví a milou se zanášeli hudbou“, „stavěli města“, „našli řemesla“, „s robotou pilných ruk [...] rozličný obchod, rozličné vedli kupectvo“, „v hostinství jiné předčívali národy všecky“ (IBID.: 233-234). Putování Slovanů z pravlasti do nových sídel je ale vylíčeno $s$ množstvím dějově velmi vypjatých motivio, které $z$ příslušné pasáže činí atraktivní dobrodružnou četbu, neobvyklou v dobovém literárním kontextu. ${ }^{70}$ Jinou literární kvalitou jsou malebné popisy dvorského prostředí. ${ }^{71}$ Látkové i motivické prvky tu jistě je potřeba přiznat Hollého originálu, nicméně jejich neobvyklost v tradici českého zpracování etiologického mýtu je více než zřejmá. Vinařického specifickou zásluhou byl převod původního hexametru, který - na rozdíl od mnoha jiných časoměrných básní té doby - naprosto nepůsobí nepřirozeně a není překážkou čtenářovu souznění s textem. Z našeho hlediska je však zásadní kombinace vypjaté vlastenecky romantické mytologie s př́isně klasicistní versifikací. ${ }^{72}$ Prolínání jednotlivých diskurzů a hledání možných mezihodnot tu před oči vystupuje velmi názorně.

\section{Závěry}

Nebudeme se dále věnovat všem Vinařického textům, blíže nepřihlédneme $\mathrm{k}$ poezii pro děti, ani $\mathrm{k}$ jednotlivostem překladů. Nepíšeme ostatně autorskou monografii, nýbrž případovou studii ke vzájemnému poměru klasicismu

70) Důvodem odchodu Slovanů z Indie mělo být tsunami („Běsné moře náhle se nad břehy vyšlou / zdvihlo vodou, a na dál pozatápělo končiny bližší, / vymlelo víry nové a otevřelo dna propasti; / víc ani do vlastních se potom nevrátilo končin“; SPISY: 218), správcem lidu byl následně určen Sámo (sic!). Slované přejdou Persii, jdou kolem Babylónu k asyrským pomezím, do Arménie, pokračují přes Kavkaz, kde je v průsmyku přepadnou ze zálohy Psohlavci. Text tu hýŕí brutálními, ba kanibalními efekty („Ušlé velmi muže, dřív než braň uchápati mohli / a v řady postaveni $\mathrm{v}$ takové se nebezpečí hájit, / matky a poschycené od náruče dítky, nevládné / chlapce a na vdání jsoucí a na krásu nezadní / panny trhat se dají, a pazourama na čtvrť drobnit / krev střebat, a ztrhané pochovávati ve břriše oudy“; IBID.: 226-227). Sámo ale poručí metat zápalné střely a jednou takovou sám zapálí chřtán psohlavského náčelníka, po vítězném boji pak „ohryzené svých sebrali kosti, / a v hroby kladli šeré a poslední uctili poctou“ (IBID.: 228).

71) „Náramná, široká v největší délku běžící / vprostřed královských pokojů se nacházela jísba“, na jejímž stropu „uměleckou líčeno štětkou“, na stolech „robeného se leskne / stříbra řada; puklaté na všech jsou ze zlata číše ze zlata číše, tvářemi ozdobené a řemeslnou v obsahu řezbou“, samozřejmě nechybí „přeskvostné úpravy jídla“ a obsluhující pážata, král má „ohromnou a vypuklou řezbami čísi, / věncovanou kvítím a pro perly a pro zlato těžkou“" (SPISY: 215-216).

72) Jiným Vinařického pokusem o literární zpracování národního mýtu je o Palackého a Chateaubrianda opřený „historický truchloděj v pěti jednáních“s titulem Jan Slepý (SPISY: 299-392; první vydání 1847 pod pseudonymem Slánský). 
a romantiky. V této souvislosti nás snad předcházející výklady opravňují $\mathrm{k}$ několika závěrům:

1. Vinařického dílo i korespondence dosvědčují v podstatě kontinuální existenci českého literárního klasicismu od počátku dvacátých do zlomu čtyřicátých a padesátých let.

2. Zároveň dokládají různorodost kontextů i funkcí klasicistních manifestací, a to $\mathrm{v}$ rozpětí od školou podnícených realizací po vyhraněné koncepty moderní literatury.

3. Názorně přitom staví před oči prolínání klasicistních prvků s prvky vlastenecké romantiky a také jejich kontrapozici vůči romantice subjektivní; tento algoritmus se jeví být nejen speciální záležitostí Vinařického, ale jedním ze základních procesů dvacátých až čtyřicátých let.

4. Z hlediska chronologického se zároveň jako podstatná jeví být optická „retrográdnost“: zatímco po raných klasicistních textech Vinařický hledal možnosti využití romantiky, a to až na hranici s její subjektivizovanou podobou, teprve po setkání s Václavem Stachem (1829) a zejména po uveřejnění Máchova Máje (1836) se znovu přiklonil ke klasicismu jako k programovému konceptu, přičemž půdu vlastenecké romantiky nikdy zcela neopustil.

5. Z tohoto úhlu pohledu se dvacátá až čtyřicátá éta jeví být mimořádně spletitým uzlovým bodem, v němž se prolínají různorodé tendence a dochází k manifestaci celé řady specifických mezihodnot.

6. Alespoň jako hypotézu lze vyslovit, že se jednalo synopse prostupnější a co do povahy vnitřně různorodější, než jaké bychom shledali později, zejména $\mathrm{v}$ případě jasněji oddělených a $\mathrm{v}$ jisté míře programově protikladných diskurzů realistického a parnasistního.

7. Návratnost identických parametrů klasicistní literatury i velmi stabilního repertoáru jejích tvárných markerů zároveň ukazuje na velmi konzistentní a v čase v podstatě neproměnnou povahu latentního klasicistního povědomí, které tvořilo kontrastivní pozadí manifestované literární tvorby po dobu více než půl století. 


\section{LITERATURA}

Antonína Jaroslava Puchmajera sebrané básně

1881 (Praha: I. L. Kober)

HAMAN, Aleš

2007 Trvání v proměně (Praha: ARSCI)

Hš (HANUŠ, Josef)

1907 „Vinařický Karel Alois“, in Ottův slovník naučný 26 (Praha: J. Otto), s. 715-719

HERZOG, Jan

1822 Básně Jana Herzoga (Praha: Josefa Vetterlová)

HOLLÝ, Ján

1824 Rozličné básně hrdinské, elegiacké, lyrické z Virgilia, Teokrita, Homéra, Ovidia, Tirtea, a Horáca (Trnava: Jan Kristián Jelínek)

HORVÁTH, Tomáš

2002 Rétorika historie (Bratislava: Veda)

IBRAHIM, Robert - PLECHÁČ, Petr - ŘíHA, Jakub

2013 Úvod do teorie verše (Praha: Akropolis)

JAKUBEC, Jan

1902 „Josef Jungmann básník a publicista. Jungmannova škola“, in Literatura česká XIX. století I (Praha: Laichter), s. 542-632

1929: Dějiny literatury české II (Praha: J. Laichter)

JANÁČKOVÁ, Jaroslava

1997 „Romantismus - biedermeier“, in Holý, J., Janáčková, J., Lehár, J., Stich, A., Česká literatura od počátků k dnešku (Praha: Nakladatelství Lidové noviny), s. 205-261

JUNGMANN, Josef

1820 Slovesnost, aneb Sbírka př́kladů s krátkým pojednáním o slohu (Praha: Josefa Vetterlová z Vildenbrunnu) 1845 Slovesnost, aneb nauka o výmluvnosti prosaické, básnické i řečnické se sbírkou príkladů v nevázané i vázané reči (Praha: Kronberger a Řivnáč)

1896 Sebrané drobné spisy veršem i prosou I (Praha: I. L. Kober)

KÁBRT, Jan (a kol.)

1957 Latinsko-český slovník (Praha: Státní pedagogické nakladatelství)

Karla Aloisa Vinařického Korrespondence a spisy pamětní I.

1903 (Praha: Česká akademie Císaře Františka Josefa pro vědy, slovesnost a umění)

\section{bohemica litteraria}


Dalibor Tureček

Karel Vinařický: Mezi klasicismem a romantikou

Karla Aloisa Vinařického Korrespondence a spisy pamětní II.

1909 (Praha: Česká akademie Císaře Františka Josefa pro vědy, slovesnost a umění)

Karla Aloisa Vinařického Korrespondence a spisy pamětní III.

1914 (Praha: Česká akademie Císaře Františka Josefa pro vědy, slovesnost a umění)

(1) Karla Al. Vinařického Sebrané spisy veršem i prosou

1871 (Praha: I. L. Kober)

KOCIÁN, Jan

1824 Básně Jana Kociána (Praha: Josefa Vetterlová z Vildenbrunnu)

KOLLÁR, Jan

1832 Slávy dcera (Pešt: Trattner a Károli)

1845 Díla básnická Jana Kollára ve dvou dílích (Budín: Gyurián a Bagó)

KRÁL, Josef

1909 Česká prosodie (Praha: J. Otto)

KRÁSNOHORSKÁ, Eliška

1990 „Obraz novějšího básnictví českého“, in Jeřábek, D. (ed.)., O národní literaturu. Z úvah a polemik doby májovců a lumírovců (Praha: Melantrich), s. 157-182

KREJČÍ, Karel

1975 Česká literatura a kulturní proudy evropské (Praha: Československý spisovatel)

KUZMÁNY, Karol

2014 Dielo (Bratislava: Kalligram - Ústav slovenskej literatury SAV)

LEHÁR, Jan - STICH, Alexandr - JANÁČKOVÁ, Jaroslava - HOLÝ, Jiří

1998 Česká literatura od počátků k dnešku (Praha: Nakladatelství Lidové noviny)

MICHALOVÁ, Rea

2007 Klasicismus v moderním umění (Praha: Michal’s collection)

NEBESKÝ, J. K.

1841 „Sněmy zvířat“, Příloha ke Květům, roč. 8, č. 5, 11. 3. 1841, s. 17-18

NERUDA, Jan

1951 Podobizny I (Praha: Československý spisovatel)

1952 Podobizny II (Praha: Československý spisovatel)

NOVÁK, Arne

1905 „Lyrika a didaktika předbřeznová v rukách epigonů“, in Literatura česká devatenáctého století III/1

(Praha: J. Laichter), s. 357-390 
1933 Literatura českého klasicismu obrozenského (Praha: Státní nakladatelství)

1936-1939 Přehledné dějiny literatury české (Olomouc: R. Promberger)

MRÁZ, Bohumír (ed.)

1988 Mácha, Karel Hynek, Hrady spatřené (Praha: Panorama)

PETRBOK, Václav

2008 „Karel Alois Vinařický“, in Lexikon české literatury 4 (Praha: Academia), s. 1352-1358

PETŘíČEK, Miroslav jr.

2009 „Komparatistika jako způsob myšlení, in Tureček, Dalibor (ed.), Národní literatura a komparatistika (Brno: Host), s. 48-55.

PŘECECHTĚL Rupert M.

1875 Českoslovanský Plutarch (Kroměříž: R. Přecechtěl)

ROŽNAY, Samuel

1812 Písně Anakreonovy z Řeckého přeložené s př́davkem některých jiných básní (Praha: František Jeřábek)

ŠAFAŘíK, Pavel Josef

1818 Počátkové českého básnictví obzvláště prozodie (Praha: J. Kramerius a J. G. Kalve)

PUCHMAJER, Antonín Jaroslav (ed.)

1814 Nové básně (Praha: František Sommer)

PUCHMAJER, Antonín Jaroslav

1881 Antonína Jaroslava Puchmajera sebrané básně (Praha: I. L. Kober)

PURKYNĚ, Jan Evangelista

1841 Bedřicha Šillera básně lyrické II (Vratislav: Ferdinand Hirt)

ŠTĚPÁNEK, Vladimír

1960 „Poezie“, in Dějiny české literatury III (Praha: Nakladatelství československé akademie věd), s. 342-367

TRNKA, František Dobromil

1821 Vesna či Básně prvotinné F. D. Trnky (Hradec Králové: J. F. Pospíšil)

TUREČEK, Dalibor

2012 České literární romantično (Brno: Host)

VAŠÁK, Pavel

1981 Literární pout Karla Hynka Máchy (Praha: Odeon)

VINAŘICKÝ, Karel Alois

1829a „Literní listy“, Časopis Společnosti Vlastenského museum v Čechách, roč. 3, s. 75-81 
Dalibor Tureček

1829b „Drobnůstky z rukopisu Starého veršovce“, Časopis Společnosti Vlastenského museum v Čechách, roč. 3 , s. $82-83$

1930 „České veršovství. Ze spisů Starého veršovce vyňato a vzděláno Karlem Vinařickým“, Časopis Společnosti Vlastenského museum v Čechách, roč. 4, s. 51-55

1834 O stanie obecnym literatury czeskiéj (Kraków: Józef Czech)

1836 „Pána Bohuslava Hasištejnského z Lobkovic věk a spisy vybrané“, in Pana Bohuslava Hasištejnského z Lobkovic věk a spisy vybrané (Praha: Václav Špinka), s. VII-LXVII

1839 „Výpisky ze Strabona“, Časopis českého museum, roč. 11, s. 269-287

1841 Coup d’ oeil sur la Littérature Bohéme de 1836 jusqu a la fin 1840 (Praha: s. n.)

1842 Kytka. Dárek malým čtenářům (Praha: J. Spurný)

1843 Varyto a lyra (Praha: Bohumil Haas)

1845 Druhá kytka básní, bajek, písní a hádanek. S obrázky a notami. Dárek malým čtenárưom (Praha: Arcibiskupská knížecí tiskárna)

1856 „O hravém rýmováni“, Škola 2, s. 56-77

1863a Sněmy zviřat (Praha: I. L. Kober)

1863b Vlast' (Praha: Rohlíček a Sievers)

1871 Sebrané spisy veršem i prosou (Praha: I. L. Kober)

VLČEK, Jaroslav

1898 Několik kapitolek z dějin naší poesie (Praha: Bursík a Kohout)

„Slovensko katolické“, in Literatura česká devatenáctého století II (Praha: J. Laichter), s. 232-264

Prof. PhDr. Dalibor Tureček, DrSc., turecek@ff.jcu.cz, Ústav bohemistiky Filozofické fakulty Jihočeské univerzity, České Budějovice, Česká republika / Department of Czech Studies, Faculty of Philosophy, University of South Bohemia, České Budëjovice, Czech Republic 